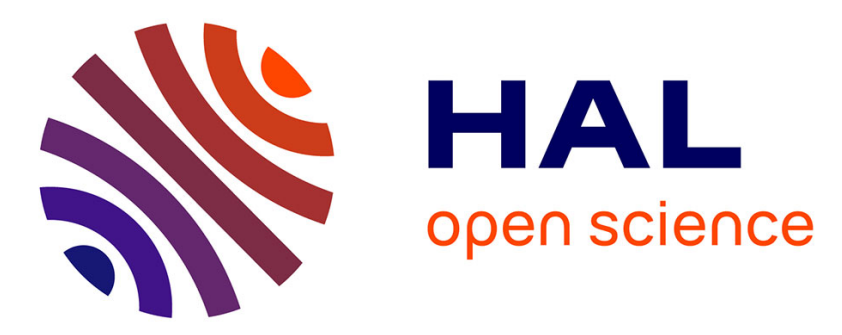

\title{
Eutrophication overcoming carbonate precipitation in a tropical hypersaline coastal lagoon acting as a CO2 sink (Araruama Lagoon, SE Brazil)
}

Luiz Cotovicz, Bastiaan Knoppers, Carolina Régis, Daniel Tremmel, Suzan Costa-Santos, Gwenaël Abril

\section{To cite this version:}

Luiz Cotovicz, Bastiaan Knoppers, Carolina Régis, Daniel Tremmel, Suzan Costa-Santos, et al.. Eutrophication overcoming carbonate precipitation in a tropical hypersaline coastal lagoon acting as a CO2 sink (Araruama Lagoon, SE Brazil). Biogeochemistry, 2021, 156, pp.231-254. 10.1007/s10533021-00842-3 . hal-03375520

\section{HAL Id: hal-03375520 \\ https://hal.science/hal-03375520}

Submitted on 20 Oct 2021

HAL is a multi-disciplinary open access archive for the deposit and dissemination of scientific research documents, whether they are published or not. The documents may come from teaching and research institutions in France or abroad, or from public or private research centers.
L'archive ouverte pluridisciplinaire HAL, est destinée au dépôt et à la diffusion de documents scientifiques de niveau recherche, publiés ou non, émanant des établissements d'enseignement et de recherche français ou étrangers, des laboratoires publics ou privés. 
${ }^{1}$ Programa de Geoquímica, Universidade Federal Fluminense, Niterói, RJ, Brazil

$7 \quad{ }^{2}$ Instituto de Ciências do Mar, Universidade Federal do Ceará, Fortaleza, Ceará, Brazil

${ }^{3}$ Biologie des Organismes et Ecosystèmes Aquatiques (BOREA), Muséum National d'Histoire Naturelle, FRE 2030, CNRS, MNHN, IRD, SU, UCN, UA, Paris, France.

${ }^{4}$ Programa de Pós-Graduação em Biologia Marinha e Ambientes Costeiros (PBMAC), Universidade Federal Fluminense, Niterói, RJ, Brazil

* Corresponding author: Luiz C. Cotovicz Jr., lccjunior@id.uff.br (ORCID: 0000-0002-3914-8155)

Acknowledgments

The authors thank Renan Cardoso, Marcelo Muniz and Roberto Meigikos (Laboratory of Radioecology and Environmental Change-Federal Fluminense University) provided access to IRMS equipment and high valuable technical assistance in stable isotopes measurements. Luiz C. Cotovicz Jr. thanks the Fundação Cearense de Apoio ao Desenvolvimento Científico e Tecnológico (FUNCAP) for a visiting researcher grant (No.PV2-0012500405.01.00/21) at the Federal University of Ceara (Marine Sciences Institute /LABOMAR / PRPPG). This is a contribution to the France-Brazil International Research Project VELITROP (Vulnerability of Tropical Littoral Ecosystem facing eutrophication) funded by the CNRS-INEE-France, to the Brazilian Ocean Acidification Research Group (BrOA), the Red Latinoamericana de Acidificación del Océano (LAOCA), and Project FEEDBACKS (CAPES/PRINT/UFF Pr.88881.310184/2018-01). 
The carbonate chemistry was investigated in the semiarid eutrophic Araruama Lagoon (Brazil), one of the largest hypersaline coastal lagoons in the world. Spatial surveys during winter and summer periods were performed, in addition to a diurnal sampling in summer. The hypersaline waters have higher concentrations of total alkalinity (TA) and dissolved inorganic carbon (DIC) than the seawater that feed the lagoon, due to evaporation. However, TA and DIC concentrations were lower than those expected from evaporation. Calcium carbonate $\left(\mathrm{CaCO}_{3}\right)$ precipitation partially explained these deficits. The negative correlation between the partial pressure of $\mathrm{CO}_{2}$ $\left(p \mathrm{CO}_{2}\right)$ and chlorophyll $a(\mathrm{Chl} a)$ indicated that DIC was also consumed by primary producers. The uptake by photosynthesis contributes to $57-63 \%$ of DIC deviation from evaporation, the remaining credited to $\mathrm{CaCO}_{3}$ precipitation. Marked $p \mathrm{CO}_{2}$ undersaturation was prevalent at the innermost region with shallow, confined, and phytoplankton-dominated waters, with a strong enrichment of heavier carbon isotope $\left(\delta^{13} \mathrm{C}\right.$-DIC up to $5.55 \%$, and highest $\mathrm{pH}$. Oversaturation was restricted to an urbanized region, and during night-time. The lagoon behaved as a marked $\mathrm{CO}_{2}$ sink during winter $\left(-15.32\right.$ to -10.15 mmolC m $\left.\mathrm{m}^{-2} \mathrm{~d}^{-1}\right)$, a moderate sink during summer (-5.50 to $4.67 \mathrm{mmolC} \mathrm{m}^{-2} \mathrm{~d}^{-1}$ ), with a net community production (NCP) of $93.7 \mathrm{mmolC} \mathrm{m}^{-2} \mathrm{~d}^{-1}$ and prevalence of net autotrophic metabolism. A decoupling between $\mathrm{CO}_{2}$ and $\mathrm{O}_{2}$ exchange rate at the air-water interface was attributed to differences in gas solubility, and high buffering capacity. The carbonate chemistry reveals simultaneous and antagonistic actions of $\mathrm{CaCO}_{3}$ precipitation and autotrophic metabolism on $\mathrm{CO}_{2}$ fluxes, and could reflect future conditions in populated and semiarid coastal ecosystems worldwide.

Key-words: carbonate chemistry; coastal eutrophication; hypersaline waters; climate change; atmospheric $\mathrm{CO}_{2}$ 


\section{Introduction}

Carbon is continuously displaced laterally and vertically along the land-ocean aquatic continuum comprising freshwaters, estuaries, and coastal areas (Regnier et al. 2013). Compared to the open ocean, the coastal ocean represents an important carbon sink (Cao et al. 2020) and plays a disproportionate role despite its modest surface

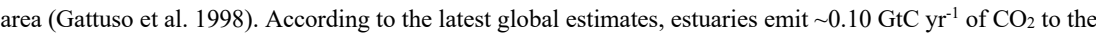

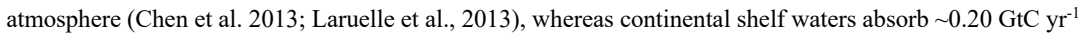
(Roobaert et al. 2019); however, these fluxes are still highly uncertain owing to the complexity of processes involved in these air-sea $\mathrm{CO}_{2}$ fluxes (Borges 2005). One of the main issues to be solved is the intrinsic spatiotemporal variability related to the heterogeneity of coastal ecosystems in different climatic domains (Borges and Abril 2011). In addition, important temporal variabilities at the tidal, diurnal, seasonal, annual and inter-annual time scales should be addressed (Borges 2005). Furthermore, anthropogenic impacts of global change and land and water uses have increased in coastal zones and have modified the biogeochemical cycles, particularly through nutrient pollution and eutrophication (Howarth et al. 2011). Coastal lagoons cover about $13 \%$ of the coastal areas (Kjerfve 1994). They are very productive ecosystems, sustaining high rates of benthic and/or planktonic primary production (Knoppers et al. 1999; Maher and Eyre 2012). Coastal lagoons present ideal conditions for human settlement, hosting $\sim 14.4 \%$ of the global population (Kjerfve 1994), but suffering the increasing symptoms of demographic expansions mainly via urbanization and sewage discharge (Knoppers and Kjerfve 1999). Few studies have investigated carbonate chemistry dynamics and air-water $\mathrm{CO}_{2}$ fluxes in coastal lagoons. Findings in tropical and subtropical coastal lagoons indicate that they can act both as net $\mathrm{CO}_{2}$ sources or sinks depending on hydrological, chemical, and biological characteristics which are affected by natural and anthropogenic-derived disturbances, especially the inputs of nutrients and dissolved carbon from the watershed (Koné et al. 2009; Ribas-Ribas et al. 2011; Ávila-López et al. 2016; Maher et al. 2019). Furthermore, Koné et al. (2009) postulated that physical settings (mixed versus stratified water column) play an important role modulating air-water $\mathrm{CO}_{2}$ fluxes.

In productive coastal waters, the carbonate chemistry is strongly influenced by the processes of primary production and microbial respiration of organic matter (Maher and Eyre 2012; Koné et al. 2009; Maher et al. 2019). In estuarine and coastal ecosystems, the acid-base properties of waters are driven by ecosystem primary 
production and respiration, $\mathrm{CaCO}_{3}$ precipitation, $\mathrm{CaCO}_{3}$ dissolution, air-water $\mathrm{CO}_{2}$ fluxes and thermodynamic equilibration during mixing of freshwater with seawater (Cai et al. 2020; Abril et al. 2021). Ecosystems that are net sinks of $\mathrm{CO}_{2}$ are generally autotrophic (gross primary production, GPP > community respiration, $\mathrm{CR}$ ), and ecosystems that are net sources of $\mathrm{CO}_{2}$ are generally heterotrophic ( $\mathrm{GPP}<\mathrm{CR}$ ) (Borges and Abril 2011).

However, many exceptions exist where autotrophic systems are $\mathrm{CO}_{2}$ sources and heterotrophic systems are $\mathrm{CO}_{2}$ sinks (Borges 2005; Cotovicz et al. 2020; Abril et al. 2021). In addition, the diurnal variability of carbonate chemistry parameters and associated air-water $\mathrm{CO}_{2}$ fluxes are significant in productive ecosystem (Cotovicz et al. 2015). Estuarine systems and near-shore coastal waters are considered as significant sources of $\mathrm{CO}_{2}$ to the atmosphere due to their heterotrophic character and inputs of $\mathrm{CO}_{2}$-enriched waters from rivers and intertidal vegetated areas (Cai et al. 1999; Cai et al. 2011; Borges and Abril 2011). However, net uptake of atmospheric $\mathrm{CO}_{2}$ has been found in coastal ecosystem located in tropical (Koné et al. 2009; Cotovicz et al. 2015) and subtropical (Maher and Eyre 2012; Kubo et al. 2017) regions. The sink behavior is often associated to humaninduced coastal eutrophication stimulating high levels of phytoplanktonic primary production (Cotovicz et al. 2015; Kubo et al. 2017). Capture of atmospheric $\mathrm{CO}_{2}$ also occurs in coastal lagoons as the result of vertical haline stratification that favors phytoplankton development (Koné et al., 2009). However, the enhancement of primary production by eutrophication is associated to a concomitant enhancement of respiratory processes and emissions of $\mathrm{CO}_{2}$ to the atmosphere (Cai et al. 2011). These processes can be tracked by analyzing the stable isotope signatures of the DIC $\left(\delta^{13} \mathrm{C}\right.$-DIC) due to the preferential uptake of the lighter stable carbon isotope $\left({ }^{12} \mathrm{C}\right)$ during photosynthesis, turning the residual DIC enriched in the heavier carbon isotope $\left({ }^{13} \mathrm{C}\right)$ (Mook 2001). For that reason, the $\delta^{13} \mathrm{C}$-DIC of phytoplankton-dominated coastal waters show very positive values (Cotovicz et al., 2019; 2020). The ecosystem-level responses of carbonate chemistry in face to eutrophication are antagonists and site-specific exerting both positive and negative feedbacks on the process of coastal and ocean acidification by increasing or decreasing the aquatic levels of $\mathrm{CO}_{2}$.

Among tropical lagoons, hypersalinity is a common characteristic in arid and semiarid regions (Kjerfve et al. 1996). The aridity is increasing worldwide as the result of climate change (Huang et al. 2017). Observations and modelling of future scenarios suggest an increase of evaporation compared to precipitation in arid/semiarid regions; in other words, arid and semiarid regions tend to be larger and drier (Chou et al. 2009; Huang et al. 2017). Currently, semiarid regions cover $\sim 15 \%$ of the Earth's continental surface (Safriel and Adeel 2005). However, the area of global drylands will expand $\sim 10 \%$ by 2100 , from inland regions to coastal zones (Feng and $\mathrm{Fu} 2013$ ). In such ecosystems, the water balance during dry months is normally negative, when the water 
loss by evaporation exceeds the water inputs by rainfall and riverine contribution. During evaporation of seawater, the concentration of dissolved salts increases in the remaining water, which become hypersaline (some authors call this remaining aqueous solution as "brines"; Babel and Schreiber, 2014). The negative water balance has the potential to change the carbonate chemistry, increasing the concentrations of TA and DIC compared to the initial concentration of seawater (Golan et al. 2016; Yao and Hu 2017; McCutcheon et al. 2019). If the weather conditions remain dry and warm and evaporation continues at high rates, salts can precipitate, $\mathrm{CaCO}_{3}$ being the first salt to form (Babel and Schreiber 2014). The precipitation of $\mathrm{CaCO}_{3}$ releases $\mathrm{CO}_{2}$ in the water, while TA and DIC are consumed in a ratio of 2:1 for every mole of $\mathrm{CaCO}_{3}$ precipitated (Dickson 2010). To the contrary, $\mathrm{CaCO}_{3}$ dissolution can occur in areas of organic matter degradation, absorbing $\mathrm{CO}_{2}$ from the water and releasing TA and DIC (Abril et al. 2003). The $\mathrm{CaCO}_{3}$ precipitation consumes DIC from the water in the form of carbonate $\left(\mathrm{CO}_{3}{ }^{2-}\right)$, which is the DIC form that has the heavier carbon stable isotope signature, turning the remaining DIC pool slightly depleted in ${ }^{13} \mathrm{C}$ relative to the initial seawater (Zhang et al. 1995; Isaji et al. 2017). These increases in TA and DIC concentrations affect the saturation state of $\mathrm{CaCO}_{3}$ minerals $(\Omega)$, the buffering capacity of the ecosystem, and the air-water $\mathrm{CO}_{2}$ fluxes (Frankignoulle 1994; Frankignoulle et al. 1994; Egleston et al. 2010). Hypersalinity may also lead to biological changes in the ecosystem in terms of abundance and diversity (Breaux et al., 2009) and, consequently, changes in the carbonate chemistry. Furthermore, the ongoing long-term sea-level rise is expected to have a significant impact on the water chemistry of coastal lagoons in some regions (Anthony et al., 2009), which will interact with the impacts of increasing eutrophication and aridity in a near future.

As noted above, eutrophication and hypersalinity drive the carbonate chemistry in specific pathways. The primary productivity consumes DIC (and $\mathrm{CO}_{2}$ ) from the water, and makes the $\delta^{13} \mathrm{C}$-DIC signatures heavier. In contrast, the $\mathrm{CaCO}_{3}$ precipitation also consumes DIC (but releases $\mathrm{CO}_{2}$ ), and this process makes the $\delta^{13} \mathrm{C}$-DIC lighter. To our best knowledge, the effects of eutrophication on carbonate chemistry of hypersaline coastal waters are almost undocumented. Araruama Lagoon, located at the Southeast coast of Brazil, is one of the largest hypersaline coastal lagoon in the world (Kjerfve et al. 1996). The system has been suffering from increasing anthropogenic disturbances along and within the watershed, especially urbanization receiving high amounts of domestic effluents. Here we report on carbonate chemistry in the Araruama Lagoon, were both processes of primary production and $\mathrm{CaCO}_{3}$ precipitation are intense and competing. We investigated the main controls on the air-water $\mathrm{CO}_{2}$ fluxes and carbonate chemistry considering the spatial and temporal variabilities. 


\section{Material and Methods}

2.1 Study Area

The Araruama Lagoon (Fig. 1), located in the state of Rio de Janeiro (Brazil), is one of the largest permanent hypersaline lagoon in the world, covering $220 \mathrm{~km}^{2}$, and composed of seven elliptical-shaped cells (Kjerfve et al. 1996; Knoppers et al. 1996). The average depth is $3 \mathrm{~m}$, with a maximum of $17 \mathrm{~m}$ in the unique channel that connects the bay to the ocean. The lagoon is $40 \mathrm{~km}$ long and $13 \mathrm{~km}$ wide at maximum, with a total water volume of about $0.62 \mathrm{~km}^{3}$ (Kjerfve et al. 1996). The climate in the region is semiarid, with a mean annual rainfall of 800 mm (Barbiére and Monteiro1974). The lagoon exhibits an excess of evaporation compared to precipitation and drainage from its very small freshwater basin. The lagoon waters are hypersaline (Barbiére and Monteiro 1974; Kjerfve et al. 1996). Historical data indicate that salinity in the lagoon is on average 52 and oscillates seasonally in response to the balance between evaporation and precipitation (Kjerfve et al. 1996). The wind velocities in the region are high, with annual averages $>6 \mathrm{~m} \mathrm{~s}^{-1}$ (Amarante et al. 2002). The flow of most incoming rivers is quite low (except during episodes of local heavy rain), with a mean annual surface runoff estimated at about $1 \mathrm{~m}^{3} \mathrm{~s}^{-1}$ (Kjerfve et al. 1996). Owing to the restricted connection with the open ocean, the time necessary to renew $50 \%$ of the water in the lagoon with seawater is estimated at about 83 days (Kjerfve et al. 1996). In the 70's-80' years, the embayment was classified as oligotrophic (Knoppers et al. 1996). At that time, studies have documented blue and crystalline waters with healthy beaches, mangroves, sandbanks and dune areas (Bertucci et al. 2016). The primary production was dominated by microphytobenthos, which greatly exceeded the planktonic primary production (Knoppers et al. 1996). However, intensive urbanization in the 80's and 90's, with absence or inefficient wastewater treatment, have led to a dramatic increase in organic matter and nutrients concentrations in the lagoon waters and sediments (Moreira-Turcq 2000; Souza et al. 2003). In addition, the settlement of an industry of carbonates extraction in the lagoon (Anomalocardia brasiliana shells for calcareous manufacture) in the 60's has increased the sediment remobilization (Kjerfve et al. 1996; Bertucci et al. 2016). This industry was decommissioned in 2006. All these factors have contributed to environmental degradation, turning the waters turbid, with an increase of planktonic primary production and a shift from oligotrophic to mesotrophic / eutrophic conditions (Knoppers et al. 1999; Souza et. al. 2003; Laut et al. 2020). 
Two sampling campaigns were conducted in the lagoon, in winter (from 17 to 20 of July-2017) and summer (from 19 to 22 of February-2018) conditions. The sampling consisted in spatial surveys covering the major area of the lagoon using a medium-size boat, with continuous real-time measurements and discrete sampling (Fig. 1). Continuous measurements included partial pressure of $\mathrm{CO}_{2}$ in the water $\left(p \mathrm{CO}_{2}\right), \mathrm{pH}$, salinity, temperature, dissolved oxygen (DO) concentrations and geographical position. Discrete sampling of surface waters was performed for determination of TA, stable isotopic composition of DIC $\left(\delta^{13} \mathrm{C}\right.$-DIC), and photosynthetic pigments (chlorophyll $a$ and pheopigments). During the sampling of February-2018, we also performed a diurnal sampling at an anchored station located at the central region of the lagoon (Fig. 1), also with continuous measurements and hourly discrete sampling during 22 hours. We could not achieve a complete 24 hours of diurnal sampling due to logistical limitations

\subsubsection{Continuous measurements}

The continuous measurement system allows real-time (every minute) record of surface water $p \mathrm{CO}_{2}$ and ancillary parameters (Frankignoulle et al. 2001). A water pump positioned at depth of $\sim 0.2 \mathrm{~m}$ supplies water continuously to an equilibrator system at a rate of $\sim 3 \mathrm{~L} \mathrm{~min}^{-1}$. The equilibrator consists of an acrylic cylinder (diameter of 8 $\mathrm{cm}$, height of $100 \mathrm{~cm}$ ), where the water flows from top to down. Marbles inside the equilibrator promotes an increase in the surface area, which reduces the equilibration time between gaseous and aquatic phases. A closed air circulation flows from the bottom to the top of the equilibrator at a rate of $\sim 1 \mathrm{~L} \mathrm{~min}^{-1}$. The air passes through a desiccant, and then the $p \mathrm{CO}_{2}$ in the dry air is measured by a non-dispersive infrared gas analyzer (NDIR; LICOR ${ }^{\circledR} 820$ type). Before each field cruise, the LICOR ${ }^{\circledR}$ was calibrated using three gas mixture standards ( $p \mathrm{CO}_{2}$ of 410, 1007, and 5035 ppmv; White Martins Certified Material, RJ, Brazil). $\mathrm{N}_{2}$ was used to set the zero, and the standard of $410 \mathrm{ppmv}$ to set the span. The standards of 1007 and $5035 \mathrm{ppmv}$ were used to check for linearity. The precision and accuracy of $p \mathrm{CO}_{2}$ measurements were estimated at about \pm 3 and $\pm 5 \mathrm{ppmv}$, respectively. The system is ideal for analyses of $p \mathrm{CO}_{2}$ in coastal waters because the equilibration between air and water phases is promoted in about 3 minutes (Cotovicz et al. 2016). Another part of the water flow ( $\sim 1 \mathrm{~L}$ $\min ^{-1}$ ) was directed to a home-made acrylic chamber where the ancillary parameters were continuously measured with probes. Water temperature, salinity and DO concentrations were measured with a calibrated YSI® 6600V2 multiparameter sonde inserted in the acrylic chamber. The salinity probe ( 0.01 of resolution) was calibrated before the cruise with IAPSO standard seawater and deionized water; we checked the linearity of the sensor 
along the entire 35-70 salinity range, by comparing the values observed in situ with the probe with those measured in the laboratory on five discrete water samples using a refractometer (slope $=1$ with $\mathrm{R}^{2}=0.95$ ). The DO probe (optical optode) was calibrated every day of measurements through a 1-point calibration in watersaturated air. The accuracy was estimated at about $\pm 0.2 \mathrm{mg} \mathrm{L}^{-1}$ or $2 \%$ of reading. The $\mathrm{pH}$ was determined continuously by the potentiometric method at the NBS scale ( $\mathrm{pH}_{\mathrm{NBS}}$ ), with a glass electrode sentix 41 connected to a WTW® 3310 pHmeter. The calibration of the pHmeter was made prior to and after each sampling campaign, using three NBS traceable buffer solutions: $\mathrm{pH} 4.00, \mathrm{pH} 7.01$ and $\mathrm{pH} 10.00$ (WTW® buffers). NBS refers to the National Bureau of Standards (now called NIST, National Institute of Standards and Technology). The reproducibility of $\mathrm{pH}$ measurements was typically better than 0.01 . The geographical position was determined with a GPG model Garmin ${ }^{\circledR} 60 \mathrm{CSx}$. All parameters measured continuously recorded the data at a frequency of 1 minute.

\subsubsection{Discrete sampling and laboratory analysis}

Surface waters were sampled at a depth of approximately $0.2 \mathrm{~m}$ with a Van Dorn bottle (Alfakit ${ }^{\circledR}, 2 \mathrm{~L}$ ). Water was filtered through GF/F Whatman ${ }^{\circledR}$ filters. The filters were used for the analysis of photosynthetic pigments, and the filtrate was used for the titration of TA. The filters were frozen at $-20^{\circ} \mathrm{C}$ until chlorophyll a $(\mathrm{Chl} a)$ and pheopigments analysis were done few days after the cruise. In the lab, filters were inserted in assay tubes containing $90 \%$ acetone and kept for 20 hours on the dark at $4{ }^{\circ} \mathrm{C}$. The pigments were quantified spectrophotometrically before and after acidification of the samples, with formulations and corrections proposed by Lorenzen (1967). The total pigments content was considered as the sum between Chl $a$ and pheo-pigments. The analyses of TA were carried out with an automatic titration system (Mettler Toledo ${ }^{\circledR} \mathrm{T} 5$ ) using $\mathrm{HCl} 0.1 \mathrm{~N}$. The equivalent point was calculated by linearizing the Gran function (Gran 1952). Measurements were compared to certified reference material (CRM, provided by A. G. Dickson from Scripps Institution of Oceanography) and corrected according. The precision and accuracy of the measurements were estimated at \pm 3 and $\pm 5 \mu \mathrm{mol} \mathrm{kg}^{-1}$, respectively.

The analytical procedures for $\delta^{13} \mathrm{C}$-DIC are described in Gillikin and Bouillon (2007). Samples for $\delta^{13} \mathrm{C}$-DIC were collected in $120 \mathrm{ml}$ of serum glass bottles. $100 \mu \mathrm{L}$ of saturated mercuric chloride was added to the samples to inhibit microbial activity. In the laboratory, a headspace of $40 \mathrm{~mL}$ was created by adding helium gas. After creating the headspace, samples were acidified adding $\mathrm{H}_{3} \mathrm{PO}_{4}$ to convert all inorganic carbon to $\mathrm{CO}_{2}$. Samples were shaken and let stabilize at room temperature for $5 \mathrm{~h} . \delta^{13} \mathrm{C}$ of $\mathrm{CO}_{2}$ in the headspace was determined with an 
isotopic ratio mass spectrometer (IRMS, Micromass IsoPrime), equipped with a manual gas injection port. The $\delta^{13} \mathrm{C}$-DIC values were corrected for the partitioning of $\mathrm{CO}_{2}$ between the gaseous (headspace) and water phases in each sample using the algorithm of Miyajima et al. (1995). $\delta^{13} \mathrm{C}$-DIC measurements were calibrated against certified standard $(\mathrm{C} 2,-8.25 \%)$. The reproducibility of the analysis was approximately $0.2 \%$. The $\delta^{13} \mathrm{C}$-DIC signatures are reported in \%o relative to the standard Vienna Pee Dee Belemnite (V-PDB) scale.

2.3 Calculations

\subsubsection{Carbonate System}

DIC was calculated from the pair TA- $p \mathrm{CO}_{2}$, at in situ seawater temperature, and salinity, using the $\mathrm{CO} 2$ calc 1.2.9 program (Robbins et al. 2010). The dissociation constants for carbonic acid were those proposed by Mehrbach et al. (1973) refitted by Dickson and Millero (1987), the borate acidity constant from Lee et al. (2010), the dissociation constant for the $\mathrm{HSO}_{4}^{-}$ion from Dickson (1990), and the solubility coefficient of $\mathrm{CO}_{2}$ from Weiss (1974). The dissociation constants of carbonic acid in natural seawater are available for limited ranges of temperature $\left(0-50^{\circ} \mathrm{C}\right)$, and salinities $(0-50)$ (Chen et al. 2015). The upper values of the salinity ranges measured in Araruama Lagoon (39.0-56.5 in winter; 33.7-65.9 in summer) are above this limit. We extrapolated linearly the values of these constants as a function of salinity, in accordance with findings in other evaporative environments with similar salinity ranges where the dissociation constants were measured (Sass and Ben-Yaakov 1977; Burke and Atkinson 1988).

2.3.2 Air-water $\mathrm{CO}_{2}$ fluxes

Diffusive $\mathrm{CO}_{2}$ fluxes at air-water interface $\left(\mathrm{FCO}_{2}\right)$ were computed according to:

$\mathrm{FCO}_{2}=\mathrm{k} \alpha \Delta p \mathrm{CO}_{2}$

(Eq. 1)

where $\mathrm{k}$ is the $\mathrm{CO}_{2}$ gas transfer velocity, $\alpha$ is the solubility of $\mathrm{CO}_{2}$ in seawater (Weiss 1974), and $\Delta p \mathrm{CO}_{2}$ is the difference between $p \mathrm{CO}_{2}$ measured in the water and in the air. Negative values represent a sink of $\mathrm{CO}_{2}$. We used the k-wind parameterization of Jiang et al. (2008; J08) and Van Dam et al. (2019; VD09), which are coefficients specific for estuaries, and the coefficient of Wanninkhof (2014; W14), which is specific for open ocean waters. The gas transfer coefficients were normalized to a Schmidt number of 600 obtained with the three parameterizations and converted to the gas transfer velocity at in situ temperature and salinity, following the procedure of Jähne et al. (1987). Fluxes were computed for each sector of Araruama Lagoon (inner, central and outer sectors; Fig. 1), using water $p \mathrm{CO}_{2}$ values and wind conditions representative for each day of sampling 
campaign. The annual budget was spatially and temporally integrated. Wind speed data were provided by the National Institute for Space Research (INPE), in a meteorological station located in the Cabo Frio city (at the mouth of the lagoon). The wind velocities in the region are strong and homogeneous due to the flat relief (Amarante et al. 2002)

\subsubsection{Net Community Production (NCP)}

The NCP can be calculated by considering the changes in DIC concentrations from the diel-moored station, and corrected for $\mathrm{CaCO}_{3}$ precipitation/dissolution and air-sea $\mathrm{CO}_{2}$ flux, according to the following equation:

$\mathrm{NCP}=\left(\left(\mathrm{DIC}_{1}-\mathrm{DIC}_{2}\right) p d\right) / \Delta \mathrm{t}-\left(\left(\mathrm{TA}_{1}-\mathrm{TA}_{2}\right) p d\right) / \Delta \mathrm{t}-\mathrm{FCO}_{2}$

Considering the fact that we did not observe significant differences of TA concentrations at the diel timescale, the $\mathrm{CaCO}_{3}$ precipitation/dissolution was assumed to be negligible along this period of sampling. Thus, the NCP was calculated according:

where $\mathrm{NCP}$ is in $\mathrm{mmol} \mathrm{m}^{-2} \mathrm{~h}^{-1}, \mathrm{DIC}_{1}$ and $\mathrm{DIC}_{2}$ are the salinity-normalized concentration of DIC $\left(\mathrm{mmol} \mathrm{kg}^{-1}\right)$ during two consecutive discrete sampling with one hour of interval, $p$ is the seawater density $\left(\mathrm{kg} \mathrm{m}^{-3}\right), d$ is the average depth (m), $\Delta \mathrm{t}$ represents the time interval (hour) and $\mathrm{FCO}_{2}$ is the carbon dioxide flux $\left(\mathrm{mmol} \mathrm{m}^{-2} \mathrm{~h}^{-1}\right)$ across the air-water interface. The vertical density, salinity and temperature stratification were considered negligible in the lagoon (Kjerfve et al. 1996). Values of NCP were hourly-averaged for nigh-time period (from dusk to dawn; $\mathrm{NCP}_{\text {night-time) }}$, and for daytime period (from dawn to dusk; $\mathrm{NCP}_{\text {daytime}}$ ).

\subsubsection{Evaporation carbonate chemistry model}

Araruama lagoon is hypersaline and the freshwater discharge is very small compared to the entire water volume of the lagoon (Kjerfve et al. 1996). In addition, the time necessary to renew $50 \%$ of the water in the lagoon with seawater is estimated at about 83 days (Kjerfve et al. 1996), favoring evaporative processes. Taking into account these characteristics, we adapted an evaporative carbonate chemistry model from a previous mixing model used by Jiang et al. (2008). The principle is that precipitation and evaporation create no salt flux across the air-water interface. Thus, in estuaries and lagoons with low or negligible freshwater inputs, the conservations of DIC and TA are written as: 
Where $\mathrm{S}_{\text {measured }}$ is the measured salinity, $\mathrm{S}_{\text {ocean }}$ the salinity of the ocean end-member, $\mathrm{DIC}_{\text {ocean }}$ and $\mathrm{TA}_{\text {ocean }}$ the DIC and TA concentrations of the ocean end-member. This model adapted to estuaries assumes that $\mathrm{DIC}$ conservative is the DIC concentration after the ocean end-member is diluted by a zero DIC freshwater. In the hypersaline lagoon, we applied this same approach for an evaporative environment, assuming that the ocean end-member is linearly concentrated by evaporation, salinity being conserved.

The deviation from evaporation path $(\triangle \mathrm{DIC})$ is defined as the DIC addition or loss relative to the theoretical DIC concentration during evaporation of seawater:

$\Delta \mathrm{DIC}=\mathrm{DIC}_{\text {measured }}-\mathrm{DIC}$ conservative

Where DIC measured is the measured DIC. Deviation of TA $(\triangle T A)$ from the evaporation path can be calculated in the same way. As we could not measure the ocean end-member during the winter sampling, we use the value from Cotovicz et al. (2015), which measured these parameters in an adjacent coastal region with similar salinity and water temperature and during the same month.

According to the approach of Yang et al. (2018), the difference between the $\delta^{13} \mathrm{C}$-DIC of the sample $\left(\delta^{13} \mathrm{C}\right.$ DIC measured $)$ and the $\delta^{13} \mathrm{C}$-DIC of the marine end-member $\left(\delta^{13} \mathrm{C}\right.$-DIC $\left.\mathrm{C}_{\text {ocean }}\right)$ represents the stable isotopic deviation from the marine end-member $\left(\Delta \delta^{13} \mathrm{C}-\mathrm{DIC}\right)$, as follows:
$\Delta \delta^{13} \mathrm{C}-\mathrm{DIC}=\delta^{13} \mathrm{C}-\mathrm{DIC}$ $-\delta^{13} \mathrm{C}-\mathrm{DIC}$ oce

If we consider only the process of seawater evaporation, the $\delta^{13} \mathrm{C}$-DIC $\mathrm{C}_{\text {measured }}$ is equal do the $\delta^{13} \mathrm{C}$-DIC $\mathrm{C}_{\text {ocean }}$ assuming that evaporation creates no carbon stable isotope exchanges across the air-sea interface (during evaporation of seawater the ${ }^{12} \mathrm{C}$ mass and ${ }^{13} \mathrm{C}$ masses are conserved). In addition, the relationship between $\Delta \mathrm{DIC} / \mathrm{DIC}$ ocean and $\Delta \delta^{13} \mathrm{C}$-DIC are tightly linked in coastal waters with limited and/or absent river inputs (Yang et al. 2018; Cotovicz et al. 2019). We used this assumption for hypersaline waters, considering the ratio $\Delta \mathrm{DIC} / \mathrm{DIC}$ ocean and the values $\Delta \delta^{13} \mathrm{C}$-DIC will be null considering only the evaporation, whereas positive and/or negative deviations are attributed to $\mathrm{CaCO}_{3}$ precipitation/dissolution, photosynthesis/respiration, and/or air-water $\mathrm{CO}_{2}$ exchanges (Samanta et al. 2015).

2.5 Statistical analysis 
We applied the Shapiro-Wilk test to verify the normality of data distribution. As the data set showed nonparametric distributions, we used the non-paired Mann-Whitney test to verify the statistical differences between averages of two groups for spatial (differences between sectors), and temporal (seasonal, diurnal) investigations. To compare the differences between three or more groups, we applied the Kruskal-Wallis test. Linear and nonlinear (second order polynomial) regressions were also calculated. All statistical analysis were based on $\alpha=0.05$ and were performed with the GraphPad Prism 7 software.

\section{Results}

3.1 Spatial and Seasonal Variability

Air was colder during winter, with temperature averaging $19.9 \pm 1.9^{\circ} \mathrm{C}$, while in summer temperature was $26.1 \pm$ $1.2{ }^{\circ} \mathrm{C}$, with a maximum of $31.2{ }^{\circ} \mathrm{C}$. The accumulated precipitation during 7 days before sampling was higher for the summer campaign $(35 \mathrm{~mm})$ than winter $(1.6 \mathrm{~mm})$. Water parameters analyzed in the inner, central and outer lagoon sectors, in summer and winter are shown in Table 1. The inner sector represents the most confined region of the lagoon with shallow depths $(<3 \mathrm{~m})$, comprising the four westernmost "elliptical cells" (Fig. 1). This sector is the only one that receives some freshwater runoff from two rivulets (annual average of $1 \mathrm{~m}^{3} \mathrm{~s}^{-1}$; Knoppers et al., 1999); this sector also receives the sewage effluent discharges from the Araruama city. The central sector includes the two longer and wider "elliptical cells" with a mean depth of $3 \mathrm{~m}$, a maximum depth of $17 \mathrm{~m}$, and the highest water volume and surface area. Due to the high surface area, this sector experiences strong northeasterly winds year-round, producing wind-driven currents and significant waves with heights frequently exceeding $1 \mathrm{~m}$ (Kjerfve et al., 1996). The outer sector includes the 14-km long entrance channel where the mixing between seawater and waters from the lagoon occurs. This region includes two very shallow "lagoon cells", and a narrow $4 \mathrm{~m}$ deep channel close to the lagoon mouth (Kjerfve et al., 1996). This region receives direct inputs of domestic effluents from the Cabo Frio city. The wind velocities were about the double in summer (averaging $8.0 \pm 2.5 \mathrm{~m}$ $\mathrm{s}^{-1}$ ), compared to winter (averaging $4.1 \pm 2.9 \mathrm{~m} \mathrm{~s}^{-1}$ ). The water temperature followed the same seasonal tendency, with higher temperatures in summer. The highest measured water temperature was $32.0^{\circ} \mathrm{C}$, whereas the lowest was $21.2^{\circ} \mathrm{C}$, both in the inner lagoon. During winter, the spatial variability of water temperature was low, whereas in summer the spatial difference was pronounced, with a landward increase of $\sim 4^{\circ} \mathrm{C}$. Salinities were also higher in summer than in winter (Mann Whitney test; $\mathrm{p}<0.001$ ). In general, inner and central sectors 
presented similar salinities, averaging 63 in summer and 54 in winter. The outer sector showed the highest spatial variability and lowest values, due to the connection with the ocean.

The distributions of $p \mathrm{CO}_{2}$ values in the lagoon showed marked spatial and temporal variability (Table 1; Figs. 2 and 3). The outer region revealed the highest values, averaging $225 \pm 37 \mathrm{ppmv}$ in winter and $460 \pm 108 \mathrm{ppmv}$ in summer. Following the landward direction, the $\mathrm{pCO}_{2}$ sharply decreased with intermediate values in the central sector of the bay, averaging $200 \pm 16$ ppmv in winter and $385 \pm 24 \mathrm{ppmv}$ in summer. The inner region of the lagoon presented the lowest values of $\mathrm{pCO}_{2}$, averaging $128 \pm 31$ ppmv in winter and $233 \pm 94 \mathrm{ppmv}$ in summer. Concerning the sector-averaged values, the winter sampling presented lower $p \mathrm{CO}_{2}$ compared to summer for all sectors (Mann Whitney test; $\mathrm{p}<0.0001$ ). The plot of $\mathrm{pCO}_{2}$ versus salinity showed a significant and inverse relationship (Fig. 2). The spatial variability of DO concentrations showed opposite trend compared to $p \mathrm{CO}_{2}$ during summer, but not during winter. The waters were more oxygenated in winter, exhibiting always oversaturated conditions. During summer, the levels of oxygen saturation decreased significantly (Mann Whitney; $\mathrm{p}<0.0001)$.

In general, the correlations between $p \mathrm{CO}_{2}$ and $\mathrm{DO}$ were variable and changed according to the day of sampling. In particular, we observed a drastic change in the $\mathrm{DO}$ versus $\mathrm{pCO}_{2}$ relationship from one day to the other, before and after a heavy storm in winter (when wind velocities exceeded $15 \mathrm{~m} \mathrm{~s}^{-1}$ ). For a similar $p \mathrm{CO}_{2}$ value, the DO concentration was significantly lower after the passage of the storm, with DO levels approaching the equilibrium with atmosphere whereas $p \mathrm{CO}_{2}$ levels remained well-below the atmospheric levels (Fig. 4). Temporally and spatially, water $p \mathrm{CO}_{2}$ was inversely correlated with $\mathrm{Chl} a$ concentrations $\left(\mathrm{R}^{2}=0.69, \mathrm{p}<0.0001\right.$ for winter; $\mathrm{R}^{2}=$ $0.76, \mathrm{p}<0.0001$ for summer; Fig. 5); however the linear regressions showed different slopes and intercepts considering the different sampling campaigns. The highest $\mathrm{Chl} a$ concentrations were found during summer, and at the innermost region of the lagoon (up to $151 \mu \mathrm{g} \mathrm{L}^{-1}$ ). Following an expected pattern, the values of $\mathrm{pH}$ were higher in summer and at innermost regions, showing significant and inverse correlations with $p \mathrm{CO}_{2}$.

Overall, the variabilities for TA, DIC and its stable isotope composition $\left(\delta^{13} \mathrm{C}\right.$-DIC $)$ showed different spatial trends during the sampling campaigns (Table 1). During winter, TA and DIC concentrations showed lower values in the inner region $(\mathrm{p}<0.001)$, averaging $2626 \pm 62 \mu \mathrm{mol} \mathrm{kg}{ }^{-1}$ and $1820 \pm 117 \mu \mathrm{mol} \mathrm{kg}^{-1}$, and higher values in the central region, averaging $2729 \pm 33 \mu \mathrm{mol} \mathrm{kg}{ }^{-1}$ and $2026 \pm 40 \mu \mathrm{mol} \mathrm{kg}^{-1}$, respectively. The $\delta^{13} \mathrm{C}$-DIC did not exhibit this clear spatial tendency, with values ranging from $1.29 \%$ to $1.60 \%$. During summer, TA concentrations were almost constant in the inner and central regions, averaging $2971 \pm 40 \mu \mathrm{mol} \mathrm{kg}{ }^{-1}$ and $2954 \pm$ 
$57 \mu \mathrm{mol} \mathrm{kg}{ }^{-1}$, respectively, while in the outer region the TA was significantly lower. For DIC concentrations and $\delta^{13} \mathrm{C}$-DIC signatures, spatial variability was significant, with lower values of DIC at the inner region (average of $2015 \pm 180 \mu \mathrm{mol} \mathrm{kg}{ }^{-1}$ ), coincident with highest $\delta^{13} \mathrm{C}$-DIC signatures (average of $4.11 \pm 1.09 \%$ ). Overall, considering the seasonal variability, TA, DIC concentrations and $\delta^{13} \mathrm{C}$-DIC signatures were higher in summer compared to winter, with minimum values of $2176 \mu \mathrm{mol} \mathrm{kg}{ }^{-1}, 1678 \mu \mathrm{mol} \mathrm{kg} \mathrm{kg}^{-1}$, and $1.29 \%$, and maximum of $3037 \mu \mathrm{mol} \mathrm{kg}{ }^{-1}, 2269 \mu \mathrm{mol} \mathrm{kg}{ }^{-1}$, and 5.55\%, respectively. TA distributions followed a positive trend with salinity $\left(\mathrm{R}^{2} 0.90 ; \mathrm{p}<0.001\right)$ (Fig. 2a). This trend was not verified for DIC concentrations and $\delta^{13} \mathrm{C}$-DIC, which did not vary with salinity (Fig. 2b,c). TA and DIC values were well below the calculated evaporation line, indicating a net loss of inorganic carbon in the lagoon (Fig. 2). For $\delta^{13} \mathrm{C}$-DIC, the values were overall above this line, with highest positive deviations during summer in the inner region of the lagoon, associated with low $p \mathrm{CO}_{2}$ values, and high water temperature and $\mathrm{Chl} a$ concentrations (Fig. 6). In winter, all data points were located close to the evaporation line (within the analytical error of $\pm 0.2 \%$ ). In summer, one point in the outer region was below the line, those in the central region were on the line and those in the inner region were well above. For winter and summer, the $\delta^{13} \mathrm{C}$-DIC presented lowest signatures in the outer region when the $p \mathrm{CO}_{2}$ values were at maximum.

Air-water $\mathrm{CO}_{2}$ flux $\left(\mathrm{FCO}_{2}\right)$ and ancillary parameters are shown in Table 2. Data for wind velocity and k600 were obtained for each day of sampling, and then multiplied by the sector-averaged air-water $p \mathrm{CO}_{2}$ gradient. The airwater $\mathrm{CO}_{2}$ fluxes were integrated for the entire surface area of the lagoon for winter and summer periods. The wind velocities were higher in summer compared to winter, with averages of $8.0 \pm 2.5 \mathrm{~m} \mathrm{~s}^{-1}$ and $4.1 \pm 2.9 \mathrm{~m} \mathrm{~s}^{-1}$, respectively. For both sampling campaigns, peaks of wind velocity overpassed $10 \mathrm{~m} \mathrm{~s}^{-1}$. Gas transfer velocities averaged $7.7 \pm 9.0 \mathrm{~cm} \mathrm{~h}^{-1}$ in winter and $17.9 \pm 8.3 \mathrm{~cm} \mathrm{~h}^{-1}$ in summer. Generally, k600 values calculated from the equation of Wanninkhof (2014; W14) were systematically lower than those calculated from the relationships of Van Dam et al. (2019; VD19) and Jiang et al. (2008; J08). However, at wind velocities higher than $9 \mathrm{~m} \mathrm{~s}^{-1}$, the parameterization of W14 gave higher k600 values than that of VD19. During winter, $\mathrm{FCO}_{2}$ exhibited always negative values, indicating a permanent sink of $\mathrm{CO}_{2}$, with fluxes ranging from $-19.5 \pm 2.5 \mathrm{mmolC} \mathrm{m} \mathrm{d}^{-1}$ at the inner sector, to $-8.2 \pm 1.9 \mathrm{mmolC} \mathrm{m}^{-2} \mathrm{~d}^{-1}$ at the outer sector. During summer, the inner and central regions remained a net sink of $\mathrm{CO}_{2}$, with fluxes ranging between $-19.3 \pm 9.8 \mathrm{mmolC} \mathrm{m}^{-2} \mathrm{~d}^{-1}$ to $-1.5 \pm 1.9$, while the outer region was a weak source of $\mathrm{CO}_{2}$, ranging from 6.8 to $7.9 \mathrm{mmolC} \mathrm{m}^{-2} \mathrm{~d}^{-1}$. Time-integrated $\mathrm{CO}_{2}$ fluxes, accounting for seasonal variations, revealed that the lagoon behaved as a net $\mathrm{CO}_{2}$ sink during the considered period of sampling. 
The diurnal variations of carbonate chemistry during the summer cruise are presented in Fig. 7 and Table 3.

Salinity did not present significant difference between daytime and night-time periods, suggesting moderate tidal mixing at the monitoring point (Mann Whitney Test; $\mathrm{p}>0.05$ ). Daytime water samples had higher average temperature $\left(30.0 \pm 0.3{ }^{\circ} \mathrm{C}\right)$ than nighttime samples $\left(29.5 \pm 0.3{ }^{\circ} \mathrm{C}\right)$, but with no statistical significance. $p \mathrm{CO}_{2}$ values averaged $411 \pm 11$ ppmv during nighttime and decreased to $385 \pm 25$ ppmv during daytime. The maximum $\mathrm{pCO}_{2}$ value was $432 \mathrm{ppmv}$ at dawn, whereas the minimum value was $330 \mathrm{ppmv}$ after midday, corresponding to a maximal diel amplitude of $102 \mathrm{ppmv}$. The highest values of $p \mathrm{CO}_{2}$ were coincident with highest concentrations of DIC, and lowest values of $\delta^{13} \mathrm{C}$-DIC and $\mathrm{pH}$ (Table 3). $p \mathrm{CO}_{2}$ showed strong negative correlations with DO $\left(\mathrm{R}^{2}=0.90 ; \mathrm{p}<0.0001\right), \delta^{13} \mathrm{C}$-DIC $\left(\mathrm{R}^{2}=0.80 ; \mathrm{p}<0.0001\right)$, and $\mathrm{Chl} a$ concentrations $\left(\mathrm{R}^{2}=\right.$ $0.75 ; \mathrm{p}<0.0001$ ). During the diurnal cycle, $\delta^{13} \mathrm{C}$-DIC values varied between $2.53 \%$ (nighttime) and $4.39 \%$ (daytime). The air-water $\mathrm{CO}_{2}$ fluxes showed emissions during nighttime, ranging from 1.59 to $3.25 \mathrm{mmol} \mathrm{C} \mathrm{m}^{-2}$ $\mathrm{d}^{-1}$, and from-3.99 to $-2.05 \mathrm{mmolC} \mathrm{m}^{-2} \mathrm{~d}^{-1}$ during daytime, considering the different gas transfer velocities. A net time-integrated flux was $-1.01 \mathrm{mmolC} \mathrm{m}^{-2} \mathrm{~d}^{-1}$. The NCP was $-91.4 \mathrm{mmol} \mathrm{C} \mathrm{m}^{-2} \mathrm{~d}^{-1}$ during night-time (heterotrophy), and $278.8 \mathrm{mmol} \mathrm{C} \mathrm{m} \mathrm{d}^{-1}$ during daytime (autotrophy), with a net time-integrated value of 93.7 $\mathrm{mmolC} \mathrm{m}^{-2} \mathrm{~d}^{-1}$.

\section{Discussion}

\subsection{Evidence for $\mathrm{CaCO}_{3}$ precipitation in the Lagoon}

Araruama Lagoon is a hypersaline coastal lagoon, with a negative water balance along the year associated with low freshwater inputs and high atmospheric temperatures (Kjerfve et al. 1996). The historical data shows that the salinities in the lagoon are normally in the range of 52-67 (Kjerfve et al. 1996), which are quite close to our measured values. The hypersaline conditions are reflected in the higher concentrations of TA and DIC in the brines of Araruama Lagoon, compared to the initial seawater. These increases of TA and DIC in the brines illustrate the general pattern of chemical evolution of seawater during the evaporation process in hypersaline systems (Krumgalz et al. 1980; Lazar et al. 1983). Higher concentration of TA in the water increases the buffering capacity, i.e., the ability to resist changes by transferring protons (Millero 2007; Dickson 2010; Middelburg et al. 2020). This means that the changes in carbonate chemistry (like variability of $\mathrm{pH}, p \mathrm{CO}_{2}$ ) related to additions/losses of $\mathrm{CO}_{2}$ in the ecosystem will be lower in waters with higher buffering capacity 
compared to waters with lower buffering capacity (Frankignoulle 1994; Middelburg et al. 2020). However, measured TA and DIC concentrations are still well below those predicted by the evaporation model (Fig. 2). TA and DIC do not behave conservatively and a net loss of TA and DIC occurs in the lagoon, creating negative deviations in the values of $\Delta \mathrm{TA}$ and $\Delta \mathrm{DIC}$ (Fig. 8a). Multiplying $\Delta \mathrm{TA}$ and $\triangle \mathrm{DIC}$ values by the water volume of the lagoon $\left(0.618 \mathrm{~km}^{3}\right)$, dividing by the average water depth $(7 \mathrm{~m})$ and considering the residence time of 167 days, the estimated net losses of TA are on the order of 0.08 to $0.10 \mathrm{gC} \mathrm{m}^{-2} \mathrm{~d}^{-1}$ for winter and summer, respectively, whereas for DIC these losses are 0.11 to $0.12 \mathrm{gC} \mathrm{m}^{-2} \mathrm{~d}^{-1}$. These losses of DIC are lower than the global-averaged community $\mathrm{CaCO}_{3}$ production in coral reefs $\left(140\right.$ to $\left.334 \mathrm{gC} \mathrm{m}^{-2} \mathrm{yr}^{1}\right)$, similar of $\mathrm{CaCO}_{3}$ production in seagrass meadows ( 30 to $125 \mathrm{gC} \mathrm{m}^{-2} \mathrm{yr}^{-1}$ ) and well above the precipitation rates found in carbonate rich (3.8 to $\left.5.3 \mathrm{gC} \mathrm{m}^{-2} \mathrm{yr}^{-1}\right)$ and poor (0.01 to $0.8 \mathrm{gC} \mathrm{m}^{-2} \mathrm{yr}^{-1}$ ) shelves (Iglesias-Rodriguez et al. 2011; O'Mara and Dune 2019; Champenois and Borges 2021).

If the weather conditions remains dry and warm and evaporation continues at high rates, the solution evolves from undersaturated to oversaturated conditions and some solid phases will precipitate (Babel and Schreiber, 2014; Marion et al. 2009). Carbonate minerals (aragonite, calcite, and high-magnesium calcite) are usually the salts that precipitate earliest during seawater evaporation (McCaffrey et al. 1987; Millero 2007; Morse et al. 2007; Babel and Schreiber 2014). For example, $\mathrm{CaCO}_{3}$ mineral may start to precipitate at the volume reduction ratio of about $50 \%$ from the original seawater (Isaji et al. 2017), which in the Araruama lagoon is equivalent to a salinity of $\sim 53$. For each mole of $\mathrm{CaCO}_{3}$ formed, TA decreases by two moles and DIC by one mole (Gattuso et al. 1999), which partially explains the deficits of TA and DIC (Figs. 2 and 8a). We must also point out that the saturation state of $\mathrm{CaCO}_{3}(\Omega)$ increases with temperature (Mucci 1983), and heating of water in the lagoon also favors the $\mathrm{CaCO}_{3}$ precipitation during summer conditions.

The precipitation of carbonate minerals can occurs spontaneously following the abiotic reactions of chemical thermodynamic equilibrium, or it can occurs mediated by organisms (biogenic calcification) (Morse and $\mathrm{He}$ 1993; Morse et al. 1997; Marion et al. 2009). A theoretical study applying a chemical thermodynamic model (FREZCHEM) found that carbonate precipitation begins at salinity of about 73 under pseudo-homogeneous nucleation (Marion et al. 2009). However, an experimental study investigating the evaporation path of seawater at the Morton solar salt production (Great Inagua Island - Bahamas) revealed the occurrence of $\mathrm{CaCO}_{3}$ precipitation at concentrations of about 1.8 times that of seawater, equivalent to a salinity of 63 (McCaffrey et al. 1987). This was attributed to the heterogeneous nucleation in shallow waters that are probable to contain preexisting mineral solid phases (Mcffrey et al. 1987; Marion et al. 2009). Accordingly, the presence of relevant 
carbonate and organic solid phases including planktonic micro-organisms in the water of the Araruama lagoon may favor the occurrence $\mathrm{CaCO}_{3}$ at early stages of evaporation path. Our data confirms this process in Araruama Lagoon, which is a shallow carbonate-rich and productive environment containing suspended carbonate grains in the water column as the results of intense sediment resuspension by wind and anthropogenic activities (Kjerfve et al. 1996; Knoppers et al. 1996), creating conditions for the occurrence of high $\mathrm{pH}$ and spontaneous $\mathrm{CaCO}_{3}$ precipitation. Indeed, in addition to carbonate precipitation, the primary productivity is also an important driver of inorganic carbon removal from the water column (see section 4.2). It is important to point out that the high rates of primary production may contribute - together with evaporation - to rise the supersaturation of $\mathrm{CaCO}_{3}$, thus locally counter-acting the process of ocean acidification. Indeed, $\mathrm{CaCO}_{3}$ nucleation from seawater have been associated with plankton blooms at shallow depths and hypersaline environments (Morse and He 1993). Fig. 8a allows to evaluate the relative contribution of primary production and $\mathrm{CaCO}_{3}$ precipitation to the deficits of TA and DIC in the brines of Araruama Lagoon. Indeed, the slopes of $\triangle \mathrm{TA}$ and $\triangle \mathrm{DIC}$ are consistent with simultaneous photosynthesis and $\mathrm{CaCO}_{3}$ precipitation.

The carbonate precipitation can be written as:

$\mathrm{Ca}^{2+}+2 \mathrm{HCO}_{3}{ }^{-} \rightarrow \mathrm{CaCO}_{3}+\mathrm{CO}_{2}+\mathrm{H}_{2} \mathrm{O}$

This reaction involves consumption of TA and DIC in a ratio of 2:1. The process of primary production, can be written as:

$\mathrm{CO}_{2}+\mathrm{H}_{2} \mathrm{O} \rightarrow \mathrm{CH}_{2} \mathrm{O}+\mathrm{O}_{2}$

This process has an almost negligible effect on TA, but a strong effect on DIC. In our calculation, we consider that TA is affected only by carbonate precipitation, whereas DIC is affected both by carbonate precipitation and primary production.

The effect of carbonate precipitation on DIC concentrations $\left(\triangle \mathrm{DIC} \mathrm{CaCO}_{3}\right)$, was calculated as:

$\Delta \mathrm{DIC}_{\mathrm{CaCO} 3}=\Delta \mathrm{TA} / 2$

$\Delta \mathrm{TA}$ is the deviation of TA concentration from the evaporation model, and was assumed to be influenced only by $\mathrm{CaCO}_{3}$ precipitation.

The effect of primary production on DIC concentrations $(\triangle \mathrm{DICpp})$ was calculated as follows: 
$\triangle \mathrm{DIC}$ is the deviation of DIC concentrations from the evaporation model. The effect of primary production and carbonate precipitation accounted for, respectively, $63 \%$ and $37 \%$ of the DIC deficits in the brines of Araruama during winter, and $57 \%$ and $43 \%$ during summer. This calculation reveals that even occurring $\mathrm{CaCO}_{3}$ precipitation (that is a net source of $\mathrm{CO}_{2}$ ), the lagoon remains a $\mathrm{CO}_{2}$ sink because of the photosynthesis occurring simultaneously. For the calculations exposed above, we considered that photosynthesis has a negligible effect on TA concentrations. However, in fact photosynthesis slightly increase TA (in case of preferential $\mathrm{NO}_{3}{ }^{-}$assimilation) or decrease TA (in case of preferential $\mathrm{NH}_{4}{ }^{+}$assimilation) (Abril and Frankignoulle, 2001) (Fig. 8a). $\mathrm{NO}_{3}{ }^{-}$assimilation is probably more significant than $\mathrm{NH}_{4}{ }^{+}$because $\mathrm{NO}_{3}{ }^{-}$ concentrations are about 10-times higher than $\mathrm{NH}_{4}{ }^{+}$concentrations in the lagoon (Ramos-Régis 2020). However, during summer and under rainy conditions, the concentrations of $\mathrm{NH}_{4}{ }^{+}$increase in the outer sector of the lagoon, close to a sewage outlet (Ramos-Régis 2020), and potentially changing the TA-DIC stoichiometry in this particular region.

4.2 $\mathrm{CO}_{2}$ uptake driven by enhanced biological activities and eutrophication

The eutrophication of estuaries is a widespread environmental problem and particularly enhanced in densely populated regions (Nixon 1995; Cloern et al. 2014). Despite the recent efforts to implement wastewater treatment plans in developing countries (Tong et al. 2020), the delivery of nitrogen and phosphorus is continuing to grow with urbanization and population increase (Larsen et al. 2016). This situation is more critical in the tropics where are located most low-income economies. The water quality of Araruama Lagoon reflects this tropical scenario of environmental degradation, and long-term eutrophication (Knoppers et al. 1999; Souza et al. 2003; Laut et al. 2020).

During photosynthesis, the primary producers assimilate high amounts of DIC from the water column, decreasing the levels of dissolved $\mathrm{CO}_{2}$. The uptake of $\mathrm{CO}_{2}$ is high in warm and shallow waters, and enhanced by the high availability of light and nutrients sustaining phytoplankton blooms (Cotovicz et al. 2015; Kubo et al. 2017), even in hypersaline environments (Morse and He 1993; Pages et al. 1995). High biological production enhanced by domestic nutrients was found in different estuarine types, including large river plumes (Borges and Frankignoulle 2002; Huang et al. 2015), coastal embayment's (Cotovicz et al. 2015; Kubo et al. 2017), and coastal lagoons (Koné et al. 2009; Maher et al. 2019). The lowest value of $p \mathrm{CO}_{2}$ of $70 \mathrm{ppmv}$ in Araruama Lagoon occurred within a dense bloom with the highest concentration of Chl $a$ of $152 \mu \mathrm{g} \mathrm{L}^{-1}$ (Fig. 5). However, for the same amount of phytoplankton biomass, the values of $p \mathrm{CO}_{2}$ are higher in summer than winter. This 
seasonality can be attributed to four main reasons: i) during summer, the water temperature was about $8^{\circ} \mathrm{C}$ higher, on average, than winter, meaning that temperature alone contributes to a seasonal $p \mathrm{CO}_{2}$ increase by 80 ppmv due to water heating. A similar seasonal effect of heating was reported in the Paraiba do Sul River Estuary, located close to Araruama Lagoon (Cotovicz et al., 2020); ii) inner and central sectors presented salinities averaging 63 in summer and 54 in winter, which create an additional theoretical increase of about 45 ppmv of $p \mathrm{CO}_{2}$ in summer compared to winter due to changes in water solubility (Millero 2007); iii) the levels of $\mathrm{CaCO}_{3}$ calcification ( $\triangle \mathrm{TA}$ values) are higher in summer, when water salinity and levels of evaporation were highest (Fig. 8), consuming DIC from the water column but releasing $\mathrm{CO}_{2}$ (Eq. 7); iv) finally, we observed the highest $p \mathrm{CO}_{2}$ peak (up to 844 ppmv) in the outer sector in summer (Fig.2), when the population of the city of Cabo Frio more than doubles (Bertucci et al. 2016), discharging more domestic sewage in the lagoon (Laut et al. 2016). In summary, half of the winter to summer $p \mathrm{CO}_{2}$ increase can be attributed to changes in thermodynamics due increasing temperature and salinities ( $\sim 125 \mathrm{ppmv})$. The other half is attributed to the balance between changes in DIC and TA driven mainly by autochthonous processes (primary production, respiration, $\mathrm{CaCO}_{3}$ calcification) and allochthonous sources (sewage discharge).

The lowest values of $\mathrm{pCO}_{2}(70 \mathrm{ppmv})$ found in the brines of the lagoon are comparable to those found in eutrophic coastal ecosystems; for example, 22 ppmv in Guanabara Bay, an eutrophic coastal embayment in Brazil dominated by phytoplankton blooms (Cotovicz et al. 2015); 43 ppmv in the Cheasapeake Bay (USA) due to high nutrient input stimulating large phytoplankton blooms (Chen et al. 2020). The high primary productivity leads not only to low concentrations of dissolved $\mathrm{CO}_{2}$, but also to an increase of $\mathrm{pH}$, carbonate ion $\left(\mathrm{CO}_{3}{ }^{2-}\right)$ concentration and the saturation state of $\mathrm{CaCO}_{3}$ minerals due to the thermodynamic equilibria of carbonate system in seawater (Millero 2007).

The high levels of primary production are also evidenced by the highly positive $\delta^{13} \mathrm{C}$-DIC signatures in the most shallow and phytoplankton-rich waters (inner sector). Fig. 6 corroborates this finding, as the $\delta^{13} \mathrm{C}$-DIC signature increases with increasing $\mathrm{Chl} a$ concentration (Fig. 6c), water temperature (Fig. 6b), and with decreasing $p \mathrm{CO}_{2}$ (particularly during summer in shallow warm-waters; Fig. 6a). The highest phytoplankton biomass (up to151 $\mu \mathrm{g}$ $\mathrm{L}^{-1}$ ) occurred in the warmest waters (up to $32.7^{\circ} \mathrm{C}$ ), associated with the lowest $p \mathrm{CO}_{2}$ values and the most positive $\delta^{13} \mathrm{C}$-DIC signatures $\left(5.55 \%\right.$ ). The positive correlations between $\delta^{13} \mathrm{C}$-DIC, temperature and phytoplankton biomass reveals a control of isotopic DIC fractionation by phytoplankton blooms (Van Dam et al. 2018; Cotovicz et al. 2019). $\mathrm{CaCO}_{3}$ precipitation also consumes DIC from the water but in the form of $\mathrm{CO}_{3}^{2-}$, which is the DIC form that has the heavier stable carbon isotope signature (compared to dissolved $\mathrm{CO}_{2}$ and 
$\mathrm{HCO}_{3}{ }^{-}$) (Zhang et al., 1995), turning the remaining DIC pool depleted in ${ }^{13} \mathrm{C}$ relative to the seawater (Isaji et al. 2017). However, the impact of primary production on $\delta^{13} \mathrm{C}$-DIC is much stronger than that of $\mathrm{CaCO}_{3}$ precipitation. Indeed, the marine phytoplankton-bicarbonate enrichment factor of stable carbon isotope (typically on the order of $-22.1 \%$ to $-35.5 \%$; Wong and Sackett 1978 ) is much more pronounced than calcite-bicarbonate and aragonite-bicarbonate enrichment factors (on the order of $1.0 \%$ and $2.7 \%$, respectively; Romanek et al. 1992). To our best knowledge, the highest $\delta^{13} \mathrm{C}$-DIC signature measured in Araruama Lagoon (5.55\%o) is the highest value reported in coastal and open waters worldwide.

Fig. $8 \mathrm{~b}$ shows that the data points of Araruama Lagoon are located between the theoretical vectors representing the processes of primary production/outgassing of $\mathrm{CO}_{2}$ (when DIC decrease and $\delta^{13} \mathrm{C}$-DIC increase) and $\mathrm{CaCO}_{3}$ precipitation (when both DIC and $\delta^{13} \mathrm{C}$-DIC decrease) (Samanta et al. 2015; Cotovicz et al. 2019). As the large majority of $p \mathrm{CO}_{2}$ values in the lagoon are below the equilibrium with the atmosphere, the effect of $\mathrm{CO}_{2}$ outgassing on $\delta^{13} \mathrm{C}$-DIC was considered as negligible (Fig. 2). The highest positive deviation of $\delta^{13} \mathrm{C}$-DIC signatures from the evaporation conservative model (up to 4\%) was found in phytoplankton-dominated waters, during summer (Fig. 8b). The highest negative deviation of $\delta^{13} \mathrm{C}$-DIC signatures from mixing (up to $-0.3 \%$ ) was found in low-phytoplankton waters, during winter, meaning that photosynthesis fractionates much more than $\mathrm{CaCO}_{3}$ precipitation.

The pattern of diurnal variability of $p \mathrm{CO}_{2}$ values in the lagoon, with higher values during night-time and lower values during daytime, also illustrates the influence of biological activities on short-time $\mathrm{CO}_{2}$ dynamics (Fig. 7). Strong diel variations of $\mathrm{CO}_{2}$ concentrations have been reported in productive estuarine systems worldwide as the results of net ecosystem metabolism (Yates et al. 2007; Zhang et al. 2013; Cotovicz et al. 2015). The biological activities modify not only the daily $\mathrm{pCO}_{2}$ variations in the water, but also the other carbonate chemistry parameters (Table 3 ). The diurnal variations of DIC concentrations correspond to a net community production (NCP) of $34.2 \mathrm{molC} \mathrm{m}^{-2} \mathrm{yr}^{-1}$ in Araruama Lagoon in summer. This autotrophic metabolism inside the Araruama lagoon generates a diurnal variability of $\mathrm{CO}_{2}$ fluxes, and the sink behavior. In the 90's (1993-1995), Knoppers et al. (1996) have investigated the metabolism in Araruama Lagoon and found higher rates of benthic net primary production (benthic chamber method, between 5.6 and $12.3 \mathrm{molC} \mathrm{m}^{-2} \mathrm{yr}^{-1}$ ) compared to planktonic primary production $\left({ }^{14} \mathrm{C}\right.$-method, $\left.0.6 \mathrm{molC} \mathrm{m} \mathrm{mr}^{-2}\right)$, and net heterotrophy (community respiration between 12.8 and $23.9 \mathrm{molC} \mathrm{m}^{-2} \mathrm{yr}^{-1}$ ). Within this same period (1989-1990), but in a "low salinity year", Moreira-Turcq (2000) documented higher rates of planktonic primary production $\left({ }^{14} \mathrm{C}\right.$ method, averaging $\left.13.5 \mathrm{~mol} \mathrm{C} \mathrm{m}^{-2} \mathrm{yr}^{-1}\right)$ due to this atypical condition of lower salinities. Later, applying the LOICZ (Land Ocean Interaction in the 
Coastal Zone) nutrient budget calculation, Souza et al. (2003) reported a slight net autotrophic metabolism (0.9 molC m $\left.{ }^{-2} \mathrm{yr}^{-1}\right)$. These results reveal an important shift in the ecosystem metabolism along decades, from a net heterotrophic benthic-dominated metabolism in the 90's to a net autotrophic planktonic-dominated metabolism afterwards. In addition, the changes in the evaporation-precipitation balance producing lower salinity conditions during atypical years can influence the trophic state of the ecosystem and the levels of primary production (Moreira-Turcq 2000). Our result of NCP falls in the highest range of documented values, suggesting that planktonic primary production is increasing in the lagoon as the result of eutrophication. These values are higher than those documented in other highly productive hypersaline lagoons (Cohen et al. 1977; Javor 1989). The NCP of Araruama Lagoon was also higher than the mean annual phytoplankton primary production found in a compilation of 131 estuaries worldwide ( $21 \mathrm{molC} \mathrm{m}^{-2} \mathrm{yr}^{-1}$; Cloern et al. 2014). This NCP is close to the threshold of hypertrophic classification ( $500 \mathrm{~g} \mathrm{C} \mathrm{m}^{-2} \mathrm{yr}^{-1}$ ) considering the annual phytoplankton primary production proposed by Nixon (1995)

High oversaturated conditions of $p \mathrm{CO}_{2}$ (maximum of $844 \mathrm{ppmv}$ ) were found only in the channel that connects the bay to the ocean (the most urbanized region) associated with urban wastewater discharge. A recent study found the presence of high levels of organic matter from anthropic origin in this region (Laut et al. 2020).

Mineralization of organic matter in polluted areas close to sewage networks leads to heterotrophy and $\mathrm{CO}_{2}$ outgassing (Cotovicz et al. 2015; 2021). The sampling in summer was carried out during a period of high rainfall, which favored $\mathrm{CO}_{2}$ and organic carbon inputs from urban areas.

\subsection{Apparent decoupling between $\mathrm{CO}_{2}$ and $\mathrm{O}_{2}$ dynamics in hypersaline and productive waters}

The relationship between excess of DIC (E-DIC) and apparent oxygen utilization (AOU) illustrates the specific metabolic characteristics of Araruama Lagoon (Fig. 9). E-DIC and AOU were calculated following Abril et al. (2003) and Benson and Krause (1984), respectively. In general, values of E-DIC and AOU were negative, consistent with net autotrophy in the lagoon. However, some E-DIC and AOU values were positive during nighttime. E-DIC and AOU values in the Araruama Lagoon presented strong deviations below the 1:1 line that represents the quotient between $\mathrm{CO}_{2}$ and $\mathrm{O}_{2}$ during primary production and community respiration (Fig. 9). The deviations were particularly important when values of $p \mathrm{CO}_{2}$ are very low in the water (below 300 ppmv; Fig. 9), associate with large disequilibria of $\mathrm{CO}_{2}$ concentrations between water and atmosphere. Indeed, the cycling of these gases in hypersaline and high-productive waters are not linearly coupled. It is well established that airwater exchange is faster for $\mathrm{O}_{2}$ than for $\mathrm{CO}_{2}$, due to different solubility of the two gases and the buffering effect 
of the carbonate chemistry (Garcia and Gordon 1992; Weiss 1974). The waters tend to equilibrate faster with the atmosphere for DO than for $\mathrm{CO}_{2}$ to the atmosphere because the buffering effect of bicarbonate concentration affects the $\mathrm{CO}_{2}$ concentrations, but not the $\mathrm{O}_{2}$ concentrations.

This difference between air-water exchanges for $\mathrm{O}_{2}$ and $\mathrm{CO}_{2}$ was evident comparing samplings occurred in consecutive days with marked differences in wind speed (Fig. 5). During day 18-07-2018 the wind speed was low $\left(<5.5 \mathrm{~m} \mathrm{~s}^{-1}\right)$, with high oversaturation for $\mathrm{O}_{2}$ and undersaturation for $p \mathrm{CO}_{2}$. Overnight, the wind speed increased to velocities $>14 \mathrm{~m} \mathrm{~s}^{-1}$, and fast gas-exchange occurred, causing DO concentrations to decrease from oversaturation to values close to atmosphere equilibrium; however, the values of $p \mathrm{CO}_{2}$ remained well below 400 ppmv, evidencing the decoupling between $\mathrm{O}_{2}$ and $\mathrm{CO}_{2}$ in these productive and well-buffered waters.

Furthermore, the occurrence of $\mathrm{CaCO}_{3}$ precipitation simultaneously causes additional deficits of DIC concentrations in the water, also contributing to lowering E-DIC values but not affecting AOU (Fig. 9)

However, during diurnal sampling, the data distribution of E-DIC and AOU were located close to the line 1:1, suggesting that at that timescale, primary production and total respiration (autotrophic and heterotrophic) were coupled, and largely dominated diel variations, as verified in other eutrophic and phytoplankton-dominated ecosystem (Cotovicz et al. 2015).

4.4 Atmospheric $\mathrm{CO}_{2}$ fluxes and net carbon sink in the lagoon

Araruama Lagoon is a coastal lagoon located in a region characterized by strong winds (Barbiére and Monteiro 1974; Amarante et al. 2002). The k-wind speed parameterization is one of the most critical parameters to compute the air-water $\mathrm{CO}_{2}$ fluxes from the gradient between $p \mathrm{CO}_{2}$ in surface ocean and lower atmosphere (Borges and Abril 2011; Wanninkhof 2014). Several formulations of k-wind parameterizations are available in order to account for the main driving forces of turbulence at the air-sea interface, and applying three k600 formulations allows to provide credible ranges of $\mathrm{FCO}_{2}$ estimates (Jiang et al. 2008; Wanninkhof 2014; Van Dam et al. 2019).

Classical river-dominated estuaries are considered net sources of $\mathrm{CO}_{2}$ to the atmosphere, with magnitude of emissions decreasing seaward (Borges and Abril 2011; Chen et al. 2013; Laruelle et al. 2013). The most recent global compilation of estuarine $\mathrm{CO}_{2}$ emissions reports strong sources of $\mathrm{CO}_{2}$ at inner regions of estuaries, on the order of $38.6 \mathrm{~mol} \mathrm{C} \mathrm{m}^{-2} \mathrm{yr}^{-1}$, and weak sources at outer regions with salinities $>25$, on the order of $8.4 \mathrm{~mol} \mathrm{C} \mathrm{m}^{-2}$ $\mathrm{yr}^{-1}$ (Chen et al. 2013). However, other studies in marine-dominated estuaries (coastal embayment's and lagoons) have reported $p \mathrm{CO}_{2}$ undersaturation and net $\mathrm{CO}_{2}$ sinks annually (Koné et al., 2009; Maher and Eyre 2012; 
Cotovicz et al. 2015; Kubo et al. 2017), or seasonally (Koné et al., 2009; Maher et al. 2019; Yao et al. 2020). In addition, the coastal plumes of large rivers (Mississippi, Amazon) also behave as $\mathrm{CO}_{2}$ sinks (Körtzinger 2003; Huang et al. 2015). The few data existing on semiarid/arid coastal ecosystems with permanent and/or intermittent hypersaline conditions suggest that these ecosystems are net sources of $\mathrm{CO}_{2}$, for example, in the semiarid subtropical region Mission-Aransas Estuary, Gulf of Mexico (12.4 mol C m ${ }^{-2} \mathrm{yr}^{-1}$; Yao and Hu, 2017), because heating and evaporation enhance $\mathrm{CO}_{2}$ degassing (Yao et al. 2020). In the Araruama Lagoon, the high enclosure and long residence time of waters together with high availability of nutrients and light, promoted conditions for high $\mathrm{CO}_{2}$ uptake, during both winter and summer conditions (Figs. 2 and 5), despite the occurrence of $\mathrm{CaCO}_{3}$ precipitation (Fig. 8). The annual sink in Araruama Lagoon ranged between -2.76 and $3.80 \mathrm{~mol} \mathrm{C} \mathrm{m}^{-2} \mathrm{y}^{-1}$, similar to those reported in other mesohaline coastal lagoons, including Australian Lagoons (-0.4 to $-2.0 \mathrm{molC} \mathrm{m}^{-2} \mathrm{yr}^{-1}$, Maher and Eyre 2012) and the Aby Lagoon in Ivory Coast $\left(-2.7 \mathrm{molC} \mathrm{m}^{-2} \mathrm{yr}^{-1}\right.$; Koné et al. 2009). A sink of $\mathrm{CO}_{2}$ has been found in other enclosed and eutrophic coastal ecosystems, particularly in embayment's, for example in Guanabara Bay (Brazil) (-9.6 to - $18.3 \mathrm{molC} \mathrm{m}^{-2} \mathrm{yr}^{-1}$, Cotovicz et al. 2015) and Tokyo Bay (Japan) (-3.2 molC m ${ }^{-2} \mathrm{yr}^{-1}$; Kubo et al. 2017). Even if $\mathrm{CaCO}_{3}$ precipitation occurs, Araruama Lagoon is a net sink of $\mathrm{CO}_{2}$ because eutrophication is enhancing the planktonic primary production, and overcoming $\mathrm{CaCO}_{3}$ precipitation.

\section{Conclusions}

Prevalence of negative water balance along the year (evaporation higher than precipitation), associated with low freshwaters inputs and low water renewal typical of choked lagoons, create conditions of hypersalinity in the Araruama Lagoon. The residual brines of Araruama Lagoon reflect the evaporation path of seawater. The waters of Araruama have higher concentrations of TA and DIC compared to seawater as the result of salt concentration. However, the concentrations of TA and DIC are, respectively, approximately $39-44 \%$ and $20-28 \%$ lower than those expected from the evaporation model. Spontaneous $\mathrm{CaCO}_{3}$ precipitation is occurring in the lagoon and contributed to about $37-43 \%$ of the DIC deficits, whereas the remaining $57-63 \%$ is attributed to uptake of DIC by primary producers.

The increasing human disturbances, mainly urbanization, have raised the discharges of urban effluents in the lagoon. The high availability of nutrients and the long water residence times have contributed to the development of phytoplankton blooms, particularly at the innermost-shallow region. The vast majority of $p \mathrm{CO}_{2}$ values were 
well-below the atmospheric values, generating a net annual sink of $\mathrm{CO}_{2}$ as the result of net autotrophic metabolism and overwhelming the $\mathrm{pCO}_{2}$ increase driven by $\mathrm{CaCO}_{3}$ precipitation. Oversaturated conditions of $p \mathrm{CO}_{2}$ were restricted to the region closest to sewage outfall (Itajuru Channel), and during night-time. The thermodynamic effects driven by water heating and increasing salinities were also significant and partially explained the higher values of $\mathrm{CCO}_{2}$ in summer compared to winter. Overall, the brines of Araruama are dominated by phytoplankton blooms with heavier $\delta^{13} \mathrm{C}$-DIC signatures (due to isotopic fractionation by primary production), higher values of $\mathrm{pH}$ and higher buffering capacity compared to seawater. The relationship between E-DIC and AOU presented values well-below the 1:1 line (quotient between photosynthesis and respiration), suggesting that air-water exchanges of $\mathrm{CO}_{2}$ and $\mathrm{O}_{2}$ are apparently decoupled due to solubility differences and high carbonate buffering capacity in these warm, hypersaline, and phytoplankton-dominated waters.

This study suggests that eutrophication locally amplifies the production of organic matter with important $\mathrm{CO}_{2}$ uptake, counter-acting the potential effects of ocean acidification by increasing the $\mathrm{pH}$. Eutrophication and negative water balance (hypersalinity) are modifying the nutrient cycling, plant productivity and carbon budgets in the lagoon. The aridity is increasing worldwide as the result of global warming, whereas at same time the inputs of anthropogenic-derived nutrients have increased in many coastal regions. Therefore, the specific results found in this semiarid coastal lagoon could reflects future conditions in other tropical coastal ecosystems.

\section{Declarations}

\section{Funding}

This work was supported by the Carlos Chagas Foundation for Research Support of the State of Rio de Janeiro (FAPERJ; proc. no. E-26/202.785/2016), and by the Fundação Cearense de Apoio ao Desenvolvimento Científico e Tecnológico (FUNCAP; Proc. No. INT-00159-00009.01.00/19)

Conflicts of interests

The authors have no conflicts of interest to declare that are relevant to the content of this article.

\section{References}

Abril G, Frankignoulle M (2001) Nitrogen - alkalinity interactions in the highly polluted Scheldt Basin (Belgium). Water Res 35:844-850. https://doi.org/10.1016/S0043-1354(00)00310-9 
Abril G, Etcheber H, Delille B, Frankignoulle M, Borges AV (2003) Carbonate dissolution in the turbid and eutrophic Loire estuary. Mar Ecol-Prog Ser 259:129-138. https://doi.org/10.3354/meps259129

Abril G, Libardoni B, Brandini N, Cotovicz Jr. L C, Medeiros PR, Cavalcante G, Knoppers BA (2021) Thermodynamic uptake of atmospheric $\mathrm{CO} 2$ in the oligotrophic and semiarid São Francisco estuary (NE Brazil). Ma Chem 233, 103983. https://doi.org/10.1016/j.marchem.2021.103983.

Amarante OA, Silva FJ, Rios Filho LG (2002) Atlas Eólico, Estado do Rio de Janeiro. Secretaria de Estado da Energia, da Indústria Naval e do Petróleo, Rio de Janeiro.

http://www.cresesb.cepel.br/publicacoes/download/atlas_eolico/AtlasEolicoRJ.pdf. Accessed 25 April 2021

Anthony A. Atwood J, August P et al. (2009) Coastal lagoons and climate change: ecological and social ramifications in U.S. Atlantic and Gulf coast ecosystems. Ecology and Society 14(1): 8 http://www.ecologyandsociety.org/vol14/iss1/art8/ Accessed 19 July 2021

Ávila-López MC, Hernández-Ayón JM, Camacho-Ibar VF et al. (2016) Air-Water $\mathrm{CO}_{2}$ fluxes and net ecosystem production changes in a Baja California coastal lagoon during the anomalous North Pacific warm condition. Estuaries Coast 40:792-806. https://doi.org/10.1007/s12237-016-0178-x

Babel M., Schreiber C. Geochemistry of Evaporites and Evolution of Seawater. In: Mackenzie F (ed) Treatise on Geochemistry, 2nd edn. Sediments, Diagenesis, and Sedimentary Rocks. Elsevier, Amsterdam, pp 483-560

Barbiére EB, Monteiro CA (1974) Ritmo climático e extração do sal em Cabo Frio. Rev Bras Geog 37:23-109.

Benson BB, Krause D (1984) The concentration and isotopic fractionation of oxygen dissolved in freshwater and seawater in equilibrium with the atmosphere, Limnol Oceanogr 29:620-632.

https://doi.org/10.4319/lo.1984.29.3.0620

Bertucci CT, Silva EP, Marques Junior AN, Monteiro Neto C (2016) Tourism and urbanization: environmental problems of the Araruama Lagoon, state of Rio de Janeiro, Brazil. Ambient soc 19:59-80. https://doi.org/10.1590/1809-4422ASOC137111V1942016

Borges AV, Frankignoulle M (2002) Distribution and air-water exchange of carbon dioxide in the Scheldt plume off the Belgian coast. Biogeochemistry 59: 41-67. https://doi.org/10.1023/A:1015517428985

Borges AV (2005) Do we have enough pieces of the jigsaw to integrate $\mathrm{CO}_{2}$ fluxes in the coastal ocean? Estuaries 26:3-27. https://doi.org/10.1007/BF02732750

Borges AV, Abril G (2011) Carbon dioxide and methane dynamics in estuaries. In: McLusky D, Wolanski E (eds) Treatise on Estuarine and Coastal Science. Academic Press, Amsterdam, pp 119 161.https://doi.org/10.1016/B978-0-12-374711-2.00504-0

Breaux N, Lebreton B, Palmer TA, Guillou G, Pollack JB (2019) Ecosystem resilience following salinity change in a hypersaline estuary. Estuar Coast Shelf Sci 225, 30, 106258. http://dx.doi.org/10.1016/j.ecss.2019.106258

Burke CM, Atkinson MJ (1988) Measurement of total alkalinity in hypersaline waters: values of $f_{\mathrm{H}}$. Mar Chem 25:49-55. https://doi.org/10.1016/0304-4203(88)90014-X

Cai W-J, Pomeroy LR, Moran MA, Wang Y (1999) Oxygen and carbon dioxide mass balance for the estuarineintertidal marsh complex of five rivers in the southeastern U.S. Limnol Oceanogr 44:639-649. https://doi.org/10.4319/10.1999.44.3.0639

Cai W-J, Hu X, Huang W-J et al. (2011) Acidification of subsurface coastal waters enhanced by eutrophication. Nature Geosci 4:766-770. https://doi.org/10.1038/ngeo1297

Cai W-J, Huang W-J, Luther 3rd GW et al. (2017) Redox reactions and weak buffering capacity lead to acidification in the Chesapeake Bay. Nat Commun 8:369. https://doi.org/10.1038/s41467-017-00417-7

Cai W-J, Feely RA, Testa JM et al. (2020) Natural and anthropogenic drivers of acidification in large estuaries. Annu Rev Mar Sci 13:23-55. https://doi.org/10.1146/annurev-marine-010419-011004 
Cao Z, Yang W, Zhao Y et al. (2020) Diagnosis of $\mathrm{CO}_{2}$ dynamics and fluxes in global coastal oceans. Nat Sci Rev 7:786-797. https://doi.org/10.1093/nsr/nwz105

Champenois W, Borges AV (2021) Net community metabolism of a Posidonia oceanica meadow. Limnol Oceanogr. https://doi.org/10.1002/lno.11724

Chen C-TA, Huang T-H, Chen Y-C, Bai Y, He X, Kang Y (2013) Air-sea exchanges of $\mathrm{CO}_{2}$ in the world's coastal seas. Biogeosciences 10:6509-6544. https://doi.org/10.5194/bg-10-6509-2013

Chen B, Cai W-J, Chen L (2015) The marine carbonate system of the Arctic Ocean: Assessment of internal consistency and sampling considerations, summer 2010. Mar Chem 176:174-188. http://dx.doi.org/10.1016/j.marchem.2015.09.007

Chen B, Cai W-J, Brodeur JR et al. (2020) Seasonal and spatial variability in surface $p \mathrm{CO}_{2}$ and air-water $\mathrm{CO}_{2}$ flux in the Chesapeake Bay. Limnol Oceanogr 65:3046-3065. https://doi.org/10.1002/lno.11573

Chou C, Neelin JD, Chen C-A, Tu JY (2009) Evaluating the rich-get-richer mechanism in tropical precipitation change under global warming. J Clim 22:1982-2005. https://doi.org/10.1175/2008JCLI2471.1

Cohen Y, Krumbein WE, Shilo M (1977) Solar Lake (Sinai) 2. Distribution of photosynthetic microorganisms and primary production. Limnol Oceanogr 22(4): 609-620. https://doi.org/10.4319/lo.1977.22.4.0609

Cloern JE, Foster SQ, Kleckner AE (2014) Phytoplankton primary production in the world's estuarine-coastal ecosystems. Biogeosciences 11:2477-2501. https://doi.org/10.5194/bg-11-2477-2014

Cotovicz LC Jr, Knoppers BA, Brandini N, Costa Santos SJ, Abril G (2015) A strong $\mathrm{CO}_{2}$ sink enhanced by eutrophication in a tropical coastal embayment (Guanabara Bay, Rio de Janeiro, Brazil). Biogeosciences 12:6125-6146. https://doi.org/10.5194/bg-12-6125-2015

Cotovicz LC Jr, Libardoni BG, Brandini N, Knoppers BA, Abril G (2016) Comparações entre medições em tempo real da $\mathrm{pCO} 2$ aquatica com estimativas indiretas em dois estuários tropicais contrastantes: o estuário eutrofizado da Baia de Guanabara (RJ) e o estuário oligotrofico do Rio São Francisco (AL. Quim Nov 39(10): 1206-1214. http://dx.doi.org/10.21577/0100-4042.20160145

Cotovicz LC Jr, Knoppers BA, Deirmendjian L, Abril G (2019) Sources and sinks of dissolved inorganic carbon in an urban tropical coastal bay revealed by $\delta^{13}$ C-DIC signals. Estuar Coast Shelf Sci 2020:185-195. https://doi.org/10.1016/j.ecss.2019.02.048

Cotovicz LC Jr, Vidal LO, de Rezende CE, Bernardes MC, Knoppers BA, Sobrinho RL, Cardoso RP, Muniz M, dos Anjos RM, Biehler A, Abril G (2020) Carbon dioxide sources and sinks in the delta of the Paraíba do Sul River (Southeastern Brazil) modulated by carbonate thermodynamics, gas exchange and ecosystem metabolism during estuarine mixing. Mar Chem 226:103869. https://doi.org/10.1016/j.marchem.2020.103869

Cotovicz LC Jr, Ribeiro RP, Régis CR et al. (2021) Greenhouse gas emissions $\left(\mathrm{CO}_{2}\right.$ and $\left.\mathrm{CH}_{4}\right)$ and inorganic carbon behavior in an urban highly polluted tropical coastal lagoon (SE, Brazil). Environ Sci Pollut Res. https://doi.org/10.1007/s11356-021-13362-2

Dickson AG, Millero FJ (1987) A comparison of the equilibrium constants for the dissociation of carbonic acid in seawater media. Deep-Sea Res 34:1733-1743. https://doi.org/10.1016/0198-0149(87)90021-5

Dickson AG (1990) Thermodynamics of the dissociation of boric acid in synthetic seawater from 273.15 to 318.15 K. Deep-Sea Res I Oceanogr Res Pap 37:755-766. https://doi.org/10.1016/0198-0149(90)90004-F

Dickson AG (2010) The carbon dioxide system in seawater: equilibrium chemistry and measurements. In: Riebesell U, Fabry VJ, Hansson L, Gattuso J-P (eds) Guide to Best Practices for Ocean Acidification Research and Data Reporting. Publications Office of the European Union, Luxembourg, pp 17-40

Egleston ES, Sabine CL, Morel FMM (2010) Revelle revisited: buffer factors that quantify the response of ocean chemistry to changes in DIC and alkalinity. Glob Biogeochem Cycles 24:1-9.

https://doi.org/10.1029/2008GB003407 
Feng S, Fu Q (2013) Expansion of global drylands under a warming climate. Atmos Chem Phys 13(19):1008110094. https://doi.org/10.5194/acp-13-10081-2013.

Frankignoulle, M., 1994. A complete set of buffer factors for acid/base CO2 system in seawater. J. Mar. Syst. 5, 111-118.

Frankignoulle M, Canon C, Gattuso J-P (1994) Marine calcification as a source of carbon dioxide: Positive feedback of increasing atmospheric $\mathrm{CO}_{2}$. Limnol Oceanogr 39(2):458-462. https://doi.org/10.1016/09247963(94)90026-4

Frankignoulle M, Borges AV, Biondo R (2001) A new design of equilibrator to monitor carbon dioxide in highly dynamic and turbid environments. Water Res 35: 1344-1347. https://doi.org/10.1016/S0043-1354(00)00369-9

Garcia HE, Gordon LI (1992) Oxygen solubility in seawater: better ftting equations. Limnol Oceanogr 37:13071312. https://doi.org/10.4319/10.1992.37.6.1307

Gattuso J-P, Frankignoulle M, Wollast R (1998) Carbon and carbonate metabolism in coastal aquatic ecosystems. Annu Rev Ecol Syst 29:405-434. https://doi.org/10.1146/annurev.ecolsys.29.1.405.1999

Gattuso J-P, Frankignoulle M, Smith SV (1999) Measurement of community metabolism and significance in the coral reef $\mathrm{CO}_{2}$ source-sink debate. Proc Natl Acad Sci 96:13017-13022.

https://doi.org/10.1073/pnas.96.23.13017

Gillikin DP, Bouillon S (2007) Determination of $\delta^{18} \mathrm{O}$ of water and $\delta^{13} \mathrm{C}$ of dissolved inorganic carbon using a simple modification of an elemental analyzer-isotope ratio mass spectrometer: an evaluation. Rapid Commun Mass Spectrom 21:1475-1478. https://doi.org/10.1002/rcm.2968

Golan R, Gavrieli I, Ganor J, Lazar B (2016) Controls on the pH of hyper-saline lakes - A lesson from the Dead Sea. Earth Planet Sci Lett 434:289-297. https://doi.org/10.1016/j.eps1.2015.11.022

Gran G (1952) Determination of the equivalence point in potentiometric titrations-Part II. Analyst 77:661-671. https://doi.org/10.1039/an9527700661

Howarth R (2011) Coupled biogeochemical cycles: eutrophication and hypoxia in temperate estuaries and coastal marine ecosystems. Front Ecol Environ 9(1):18-26. . https://doi.org/10.1890/100008

Huang W-J, Cai W-J, Wang Y, Lohrenz SE, Murrell MC (2015) The carbon dioxide $\left(\mathrm{CO}_{2}\right)$ system on the Mississippi River- dominated continental shelf in the northern Gulf of Mexico - I: Distribution and air-sea $\mathrm{CO}_{2}$ flux. J Geophy Res (120):1429-1445. https://doi.org/10.1002/2014JC010498

Huang J, Li Y, Fu C et al. (2017) Dryland climate change: Recent progress and challenges. Rev Geophys 55:719-778. https://doi.org/10.1002/2016RG000550

Iglesias-Rodriguez MD, Armstrong R, Feely R et al (2011) Progress made in study of oceans calcium carbonate budget. Eos 83(34):365-375. https://doi.org/10.1029/2002EO000267

Isaji Y, Kawahata H, Kuroda J et al (2017) Biological and physical modification of carbonate system parameters along the salinity gradient in shallow hypersaline solar salterns in Trapani, Italy. Geochim Cosmochim Acta 208:354-367. https://doi.org/10.1016/j.gca.2017.04.013

Jähne B, Munnich KO, Bosinger R, Dutzi A, Huber W, Libner P (1987) On parameters influencing air-water exchange. J Geophys Res 92:1937-1949. https://doi.org/10.1029/JC092iC02p01937

Javor B (1989) Hypersaline environments. Microbiology and Biogeochemistry. Brock/Spring Series in Contemporary Bioscience. Springer Verlag, Berlin

Jiang LQ, Cai W-J, Wang YC (2008) A comparative study of carbon dioxide degassing in river- and marine dominated estuaries. Limnol Oceanogr 53:2603-2615. https://doi.org/10.4319/lo.2008.53.6.2603

Kjerfve B (1994) Coastal Lagoons. In: Kjerfve B (ed) Coastal Lagoon Processes, Oceanography Series, $1^{\text {st }}$ edn. Elsevier, Amsterdam, pp 1-8 
Kjerfve B, Schettini CAF, Knoppers B, Lessa G, Ferreira HO (1996) Hydrology and salt balance in a large hypersaline coastal lagoon: Lagoa de Araruama, Brazil. Estuar Coast Shelf Sci 42: 701-725. https://doi.org/10.1006/ecss.1996.0045

Knoppers BA, Kjerfve B (1999) Coastal lagoons of Southeastern Brazil: Physical and biogeochemical characteristics. In: Perillo G, Piccolo MC (eds) Estuaries of South America. Their morphology and dynamics. Springer-Verlag, Berlin, pp 35-66

Knoppers BA, Souza WF, Souza MFL, Rodriguez EG, Landim ECV, Vieira AR (1996) In situ measurements of $\mathrm{n}$ benthic primary production, respiration and nutrient fluxes in a hypersaline coastal lagoon of SE, Brazil. Rev Bras Oceanogr 44: 155-165. https://doi.org/10.1590/S1413-77391996000200005

Knoppers BA, Carmouze J-P, Moreira-Turcq PF (1999) Nutrient dynamics, metabolism and eutrophication of lagoons along the east Fluminense coast, state of Rio de Janeiro, Brazil, In: Knoppers BA, Bidone ED, Abrão JJ (eds) Environmental geochemistry of coastal lagoon systems of Rio de Janeiro, Brazil. FINEP, Rio de Janeiro, pp 123-154.

Koné YJM, Abril G, Kouadio KN, Dellile B., Borges AV et al (2009) Seasonal variability of carbon dioxide in the rivers and lagoons of Ivory Coast (West Africa). Estuaries Coast 32:246-260.

https://doi.org/10.1007/s12237-008-9121-0

Körtzinger A (2003) A significant $\mathrm{CO}_{2}$ sink in the tropical Atlantic Ocean associated with the Amazon River plume. Geophys Res Let 30:24. https://doi.org/10.1029/2003GL018841

Krumgalz S, Hoknung H, Oren OH (1980) The study of natural hypersaline lagoons in desert areas (the Bardawil Lagoon in northern Sinai). Estuarine Coastal Mar Sci 10:403-415. https://doi.org/10.1016/S0302$3524(80) 80120-4$

Kubo A, Maeda Y, Kanda J (2017) A significant net sink for $\mathrm{CO}_{2}$ in Tokyo Bay. Sci Rep 7:44355. https://doi.org/10.1038/srep44355

Larsen TA, Hoffman S, Lüthi C, Truffer B, Maurer M (2016) Emerging solutions to the water challenges of an urbanizing world. Science 352:928-933. https://doi.org/10.1126/science.aad8641

Laruelle GG, Dürr HH, Lauerwald R et al (2013) Global multi-scale segmentation of continental and coastal waters from the watersheds to the continental margins. Hydrol Earth Syst Sci 17:2029-2051. https://doi.org/10.5194/hess-17-2029-2013

Laut L, Vilar A, Belart P et al (2020) Organic matter compounds as a tool for trophic state characterization in a hypersaline environment: Araruama Lagoon, Brazil. J South Am Earth Sci 97:102403.

https://doi.org/10.1016/j.jsames.2019.102403

Lazar B, Starinsky A, Katz A, Sass E, Ben-Yaakov S (1983) The carbonate system in hypersaline solutions: alkalinity and $\mathrm{CaCO}_{3}$ solubility of evaporated seawater. Limnol Oceanogr 28:978-986. https://doi.org/10.4319/lo.1983.28.5.0978

Lee K, Kim TW, Byrne RH et al (2010) The universal ratio of boron to chlorinity for the North Pacific and North Atlantic oceans. Geochim Cosmochim Acta 74:1801-1811. https://doi.org/10.1016/j.gca.2009.12.027

Lorenzen C (1967) Determination of chlorophyll and pheo-pigments: spectrophomometric equations. Limnol Oceanogr 12:343-346. https://doi.org/10.4319/lo.1967.12.2.0343

Maher DT, Eyre BD (2012) Carbon budgets for three autotrophic Australian estuaries: Implications for global estimates of the coastal air-water $\mathrm{CO}_{2}$ flux. Global Biogeochem Cy 26:GB1032. https://doi.org/10.1029/2011GB004075, 2012

Maher DT, Call M, Macklin P, Webb JR, Santos IR (2019) Hydrological Versus Biological Drivers of Nutrient and Carbon Dioxide Dynamics in a Coastal Lagoon. Estuaries Coast 42:1015-1031.

https://doi.org/10.1007/s12237-019-00532-2

Marion GM, Millero FJ, Feistel R (2009) Precipitation of solid phase calcium carbonates and their effect on application of seawater SA-T -P models. Ocean Sci 5:285-291. https://doi.org/10.5194/os-5-285-2009 
McCaffrey MA, Lazar B, Holland HD (1987) The evaporation path of seawater and the coprecipitation of $\mathrm{Br}^{-}$ and $\mathrm{K}^{+}$with halite. J Sediment Petrol 57:928-938. https://doi.org/10.1306/212f8cab-2b24-11d7$8648000102 \mathrm{c} 1865 \mathrm{~d}$

McCutcheon MR, Staryk CJ, Hu X (2019) Characteristics of the Carbonate System in a Semiarid Estuary that Experiences Summertime Hypoxia. Estuaries Coast 42:1509-1523. https://doi.org/10.1007/s12237-019-00588-0

Mehrbach C, Cuberson CH, Hawley JE, Pytkowicx RM (1973) Measurements of the apparent dissociation constants of carbonic acid in seawater at atmospheric pressure. Limnol Oceanog 18:897-907. https://doi.org/10.4319/lo.1973.18.6.0897

Middelburg JJ, Soetaert K, Hagens M (2020) Ocean Alkalinity, Buffering and Biogeochemical Processes. Rev Geophys 58:e2019RG000681. https://doi.org/10.1029/2019RG000681

Millero FJ (2007) The Marine Inorganic Carbon Cycle. Chem Rev 107:308-341.

https://doi.org/10.1021/cr0503557

Miyajima T, Miyajima Y, Hanba YT, Yoshii K, Koitabashi T, Wada E (1995) Determining the stable isotope ratio of total dissolved inorganic carbon in lake water by GC/C/IIRMS. Limnol Oceanogr 40:994-1000. https://doi.org/10.4319/lo.1995.40.5.0994

Mook, W. G., 2001. Environmental Isotopes in the Hydrological Cycle: Principles and applications. UNESCO, Paris

Moreira-Turcq P (2000) Impact of a low salinity year on the metabolism of a hypersaline coastal lagoon (Brazil). Hydrobiologia 429:133-140. https://doi.org/10.1023/A:1004037624787

Morse JW, He S (1993) Influences of $\mathrm{T}, \mathrm{S}$ and $\mathrm{pCO}_{2}$ on the pseudo-homogeneous precipitation of $\mathrm{CaCO} 3$ from seawater: implications for whiting formation. Mar Chem 41:291-297. https://doi.org/10.1016/03044203(93)90261-L

Morse JW, Wang Q, Tsio MY (1997) Influences of temperature and Mg:Ca ratio on the mineralogy of CaCO3 precipitated from seawater. Geology 25:85-87. https://doi.org/10.1130/0091-

7613(1997)025<0085:IOTAMC $>2.3 . C O ; 2$

Morse JW, Arvidson RS, Lüttge A (2007) Calcium carbonate formation and dissolution. Chem Rev 107:342_381. http://dx.doi.org/10.1021/cr050358j.

Nixon SW (1995) Coastal marine eutrophication: A definition, social causes, and future concerns. Ophelia 41:199-219. https://doi.org/10.1080/00785236.1995.10422044

Pages J, Lemoalle J, Fritz B (1995) Distribution of carbon in a tropical hypersaline estuary, the Casamance (Senegal, West Africa). Estuaries 18:456-468. https://doi.org/10.2307/1352364

O’Mara NA, Dune JP (2019) Hot spots of carbon and alkalinity cycling in the coastal oceans. Sci Rep 9:4434. https://doi.org/10.1038/s41598-019-41064-w

Ramos-Régis C (2021) Avaliação do estado trófico da Laguna Hipersalina de Araruama e do Complexo Lagunar de Jacarepaguá (Rio de Janeiro). Master Dissertation, Federal Fluminense University

Regnier P, Friedlingstein P, Ciais P et al (2013) Anthropogenic perturbation of the carbon fluxes from land to ocean. Nature Geosci 6:597-607. https://doi.org/10.1038/ngeo1830

Ribas-Ribas M, Hernández-Ayón JM, Camacho-Ibar VF et al (2011) Effects of upwelling, tides and biological processes on the inorganic carbon system of a coastal lagoon in Baja California. Estuar Coast Shelf Sci 95:367376. https://doi.org/10.1016/j.ecss.2011.09.017

Robbins LL, Hansen ME, Kleypas JA, Meylan SC (2010) CO2 Calc: a user-friendly seawater carbon calculator for Windows, Max OS X, and iOS (iPhone), U.S. Geological Survey Open-File Report, 2010-1280, 1-17. http://pubs.usgs.gov/of/2010/1280/. Accessed 07 December 2020 
Romanek C, Grossman E, Morse J (1992) Carbon isotopic fractionation in synthetic aragonite and calcite: Effects of temperature and precipitation rate. Geochim Cosmochim Acta 56:419-430. https://doi.org/10.1016/0016-7037(92)90142-6

Roobaert A, Laruelle GG, Landschützer P, Gruber N, Chou L, Regnier P (2019) The spatiotemporal dynamics of the sources and sinks of $\mathrm{CO}_{2}$ in the global coastal ocean. Global Biogeochem Cy 33:1693-1714. https://doi.org/10.1029/2019GB006239

Safriel U, Adeel Z (2005) Dryland systems. In: Hassan R, Scholes R, Ash N (eds) Ecosystems and Human wellbeing: Current State and Trends. Island Press, Washington DC, pp 623-62.

Samanta S, Dalai TK, Pattanaik JK, Rai SK, Mazumdar A (2015) Dissolved inorganic carbon (DIC) and its $\delta 13 \mathrm{C}$ in the Ganga (Hooghly) River estuary, India: evidence of DIC generation via organic carbon degradation and carbonate dissolution. Geochem Cosmochim Acta 165:226-248. https://doi.org/10.1016/j.gca.2015.05.040

Sass E, Ben-Yaakov S (1977) The carbonate system in hypersaline solutions: Dead Sea Brines. Mar Chem 5:183-199. https://doi.org/10.1016/0304-4203(77)90006-8

Souza MF, Kjerfve B, Knoppers B, Landim de Souza W, Damasceno RN (2003) Nutrient budgets and trophic state in a hypersaline coastal lagoon: Lagoa de Araruama, Brazil. Estuar Coast Shelf Sci 57:843-858. https://doi.org/10.1016/S0272-7714(02)00415-8

Tong Y, Wang M, Peñuelas J et al (2020) Improvement in municipal wastewater treatment alters lake nitrogen to phosphorus ratios in populated regions Proc Natl Acad Sci 117(21):11566-11572. https://doi.org/10.1073/pnas.1920759117

Van Dam BR, Tobias C, Holbach A, Paerl HW, Zhu G (2018) $\mathrm{CO}_{2}$ limited conditions favor cyanobacteria in a hypereutrophic lake: An empirical and theoretical stable isotope study. Limnol Oceanogr 63:1643-1659. https://doi.org/10.1002/lno.10798

Van Dam BR, Edson JB, Tobias C (2019) Parameterizing Air-Water Gas Exchange in the Shallow, Microtidal New River Estuary. J Geophys Res Biogeosciences 124:2351-2363. https://doi.org/10.1029/2018JG004908

Wanninkhof R (2014) Relationship between wind speed and gas exchange over the ocean revisited. Limnol Oceanogr Methods12:351-362. https://doi.org/10.4319/lom.2014.12.351

Wong WW, Sackett WM (1978) Fractionation of stable carbon isotopes by marine pbytoplankton. Geochim Cosmochim Acta 42:1809-1815.

Weiss RF (1974) Carbon dioxide in water and seawater: the solubility of a non-ideal gas. Mar Chem 2:203-215. https://doi.org/10.1016/0304-4203(74)90015-2

Yang X, Xue L, Li Y, Han P, Liu X, Zhang L, Cai W-J (2018) Treated wastewater changes the export of dissolved inorganic carbon and its isotopic composition and leads to acidification in coastal oceans. Environ Sci Technol 52(10):5590-5599. https://doi.org/10.1021/acs.est.8b00273

Yao H, Hu X (2017) Responses of carbonate system and $\mathrm{CO}_{2}$ flux to extended drought and intense flooding in a semiarid subtropical estuary. Limnol Oceanogr 62:S112-S130. https://doi.org/10.1002/lno.10646

Yao H, McCutcheon MR, Staryk CJ, Hu X (2020) Hydrologic controls on $\mathrm{CO}_{2}$ chemistry and flux in subtropical lagoonal estuaries of the northwestern Gulf of Mexico. Limnol Oceanogr 65:1380-1398.

https://doi.org/10.1002/lno.11394

Yates KK, Dufore C, Smiley N, Jackson C, Halley RB (2007) Diurnal variation of oxygen and carbonate system parameters in Tampa Bay and Florida Bay. Mar Chem 104:110-124.

https://doi.org/10.1016/j.marchem.2006.12.008

Zhang J, Quay PD, Wilbur DO (1995) Carbon isotope fractionation during gas water exchange and dissolution of $\mathrm{CO}_{2}$. Geochim Cosmochim Acta 59(1):107-114. https://doi.org/10.1016/0016-7037(95)91550-D. 
962

963

964

965

966

967

968

969

970

971

972

973

974

975

976

977

978

979

980

981

982

983

Zhang C, Huang H, Ye C, Huang L, Li X, Lian J, Liu S (2013) Diurnal and seasonal variations of carbonate system parameters on Luhuitou fringing reef, Sanya Bay, Hainan Island, South China Sea, Deep-Sea Res Pt II 96:65-74. https://doi.org/10.1016/j.dsr2.2013.02.013

7

0

1

3

65

67

69

70

72

74

75

76

78

79

80

982


Table 1: Mean ( \pm standard deviation) and ranges of the principal parameters investigated in the brines of Araruama Lagoon, separated by sectors and sampling campaigns.

\begin{tabular}{|c|c|c|c|c|c|c|}
\hline & \multicolumn{3}{|c|}{ July-2017 (winter) } & \multicolumn{3}{|c|}{ February-2018 (summer) } \\
\hline & $\begin{array}{c}\text { Inner } \\
\text { Lagoon }\end{array}$ & $\begin{array}{l}\text { Central } \\
\text { Lagoon }\end{array}$ & $\begin{array}{c}\text { Outer } \\
\text { Lagoon } \\
\text { (channel) }\end{array}$ & $\begin{array}{l}\text { Inner } \\
\text { lagoon }\end{array}$ & $\begin{array}{l}\text { Central } \\
\text { Lagoon }\end{array}$ & $\begin{array}{c}\text { Outer } \\
\text { Lagoon } \\
\text { (channel) }\end{array}$ \\
\hline Salinity & $\begin{array}{c}53.4 \pm 1.5 \\
(49.955 .5)\end{array}$ & $\begin{array}{c}55.0 \pm 1.3 \\
(39.056 .4)\end{array}$ & $\begin{array}{c}53.3 \pm 2.6 \\
(36.756 .5)\end{array}$ & $\begin{array}{c}64.3 \pm 0.7 \\
(62.465 .9)\end{array}$ & $\begin{array}{l}62.8 \pm 1.8 \\
(53.465 .3\end{array}$ & $\begin{array}{l}43.84 \pm 8.6 \\
(33.764 .8)\end{array}$ \\
\hline $\begin{array}{c}\text { Temperature } \\
\left({ }^{\circ} \mathrm{C}\right)\end{array}$ & $\begin{array}{l}21.8 \pm 0.2 \\
(21.022 .6)\end{array}$ & $\begin{array}{c}21.8 \pm 0.3 \\
(19.723 .3)\end{array}$ & $\begin{array}{c}22.5 \pm 0.9 \\
(19.024 .0)\end{array}$ & $\begin{array}{l}31.2 \pm 0.7 \\
(29.832 .7)\end{array}$ & $\begin{array}{l}29.9 \pm 0.8 \\
(27.032 .1\end{array}$ & $\begin{array}{l}27.4 \pm 1.9 \\
(24.932 .3)\end{array}$ \\
\hline $\begin{array}{c}\text { pH } \\
\text { (NBS) }\end{array}$ & $\begin{array}{l}8.69 \pm 0.09 \\
(8.568 .88)\end{array}$ & $\begin{array}{l}8.53 \pm 0.02 \\
(8.428 .61)\end{array}$ & $\begin{array}{l}8.51 \pm 0.05 \\
(8.388 .71)\end{array}$ & $\begin{array}{l}8.49 \pm 0.16 \\
(8.308 .84)\end{array}$ & $\begin{array}{c}8.28 \pm 0.05 \\
(7.948 .41\end{array}$ & $\begin{array}{l}8.25 \pm 0.08 \\
(7.868 .39)\end{array}$ \\
\hline $\begin{array}{c}\text { TA } \\
\left.(\mu \mathrm{mol} \mathrm{kg})^{-1}\right)\end{array}$ & $\begin{array}{c}2626 \pm 62 \\
(25362686)\end{array}$ & $\begin{array}{c}2729 \pm 33 \\
(26602772)\end{array}$ & $\begin{array}{l}2642 \pm 111 \\
25432770)\end{array}$ & $\begin{array}{c}2971 \pm 40 \\
(29313037)\end{array}$ & $\begin{array}{c}2954 \pm 57 \\
(28443003\end{array}$ & $\begin{array}{l}2483 \pm 285 \\
(21762925)\end{array}$ \\
\hline $\begin{array}{c}\text { DIC } \\
\left.(\mu \mathrm{mol} \mathrm{kg})^{-1}\right)\end{array}$ & $\begin{array}{r}1820 \pm 117 \\
(16781965)\end{array}$ & $\begin{array}{c}2026 \pm 40 \\
(19362058)\end{array}$ & $\begin{array}{c}1970 \pm 43 \\
19362029)\end{array}$ & $\begin{array}{l}2015 \pm 180 \\
(17952220)\end{array}$ & $\begin{array}{c}2225 \pm 35 \\
(21642269) \\
\end{array}$ & $\begin{array}{c}2037 \pm 112 \\
(18662217)\end{array}$ \\
\hline $\begin{array}{c}\delta^{13} \mathrm{C}-\mathrm{DIC} \\
(\% 0)\end{array}$ & $\begin{array}{l}1.50 \pm 0.19 \\
(1.291 .79)\end{array}$ & $\begin{array}{c}1.58 \pm 0.12 \\
1.411 .78)\end{array}$ & $\begin{array}{c}1.67 \pm 0.20 \\
1.381 .82)\end{array}$ & $\begin{array}{l}4.11 \pm 1.09 \\
(2.725 .55)\end{array}$ & $\begin{array}{l}2.77 \pm 0.26 \\
(2.433 .26)\end{array}$ & $\begin{array}{c}2.69 \pm 0.40 \\
1.943 .11)\end{array}$ \\
\hline $\begin{array}{c}\mathrm{pCO}_{2} \\
(\mathrm{ppmv})\end{array}$ & $\begin{array}{l}128 \pm 31 \\
(70182)\end{array}$ & $\begin{array}{c}200 \pm 16 \\
(152304)\end{array}$ & $\begin{array}{l}225 \pm 37 \\
(136406)\end{array}$ & $\begin{array}{l}233 \pm 94 \\
(92366)\end{array}$ & $\begin{array}{c}385 \pm 24 \\
(283435)\end{array}$ & $\begin{array}{c}460 \pm 108 \\
301844)\end{array}$ \\
\hline $\begin{array}{c}\text { DO } \\
(\% \text { Sat })\end{array}$ & $\begin{array}{c}123 \pm 4 \\
(109135)\end{array}$ & $\begin{array}{c}114 \pm 6 \\
(90153)\end{array}$ & $\begin{array}{l}121 \pm 17 \\
(62196)\end{array}$ & $\begin{array}{l}103 \pm 10 \\
(80143)\end{array}$ & $\begin{array}{c}97 \pm 7 \\
(56112)\end{array}$ & $\begin{array}{l}92 \pm 10 \\
61133)\end{array}$ \\
\hline $\begin{array}{c}\text { Chl } a \\
\left(\mu \mathrm{g} \mathrm{L^{-1 } )}\right.\end{array}$ & $\begin{array}{l}31.2 \pm 5.2 \\
(25.537 .4)\end{array}$ & $\begin{array}{c}21.4 \pm 3.8 \\
(16.326 .6)\end{array}$ & $\begin{array}{c}20.9 \pm 7.7 \\
(14.030 .5)\end{array}$ & $\begin{array}{c}75.7 \pm 49.2 \\
(26.4151 .9) \\
\end{array}$ & $\begin{array}{l}33.2 \pm 4.7 \\
(23.838 .5)\end{array}$ & $\begin{array}{c}30.3 \pm 24.9 \\
(1.071 .3)\end{array}$ \\
\hline
\end{tabular}


Table 2 Summary of calculated mean values for wind speed, gas exchange coefficient $\left(\mathrm{k}_{600}\right)$ and $\mathrm{CO}_{2}$ fluxes at the air-sea interface $\left(\mathrm{FCO}_{2}\right)$ in each sector and the whole of Araruama Lagoon. W14 is the data calculated according to $\mathrm{k}_{600}$ of Wanninkhof (2014), VD19 is the data calculated according to $\mathrm{k}_{600}$ of Van-Dam et al. (2019), and J08 is data calculated according to k600 of Jiang et al. (2008).

1009

\begin{tabular}{|c|c|c|c|c|c|c|c|}
\hline & \multirow{2}{*}{$\begin{array}{l}\text { Wind } \\
\text { velocity } \\
\left(\mathrm{m} \mathrm{s}^{-1}\right)\end{array}$} & \multicolumn{3}{|c|}{$\begin{array}{c}\mathbf{k}_{600} \\
\left(\mathrm{~cm} \mathrm{~h}^{-1}\right)\end{array}$} & \multicolumn{3}{|c|}{$\begin{array}{c}\mathrm{FCO}_{2} \\
\left(\mathrm{mmolC} \mathrm{m}^{-2} \mathrm{~d}^{-1}\right)\end{array}$} \\
\hline & & (W14) & (VD19) & (J08) & (W14) & (VD19) & (J08) \\
\hline \multicolumn{8}{|c|}{ July-2017 (Winter) } \\
\hline $\begin{array}{c}\text { Inner } \\
\left(65 \mathrm{Km}^{2}\right)\end{array}$ & $4.1 \pm 2.9$ & $7.7 \pm 9.0$ & $10.2 \pm 5.0$ & $11.6 \pm 9.9$ & $-12.9 \pm 1.7$ & $-17.1 \pm 2.6$ & $-19.5 \pm 2.5$ \\
\hline $\begin{array}{c}\text { Central } \\
\left(123 \mathrm{Km}^{2}\right)\end{array}$ & $4.1 \pm 2.9$ & $7.7 \pm 9.0$ & $10.2 \pm 5.0$ & $11.6 \pm 9.9$ & $-9.2 \pm 0.7$ & $-12.2 \pm 1.0$ & $-13.9 \pm 1.1$ \\
\hline $\begin{array}{c}\text { Outer } \\
\left(32 \mathbf{K m}^{2}\right)\end{array}$ & $4.1 \pm 2.9$ & $7.7 \pm 9.0$ & $10.2 \pm 5.0$ & $11.6 \pm 9.9$ & $-8.2 \pm 1.9$ & $-10.8 \pm 2.5$ & $-12.3 \pm 2.8$ \\
\hline $\begin{array}{c}\text { All Lagoon } \\
\text { area- } \\
\text { weighted } \\
\left(220 \mathrm{Km}^{2}\right)\end{array}$ & & & & & -10.15 & -13.44 & -15.32 \\
\hline \multicolumn{8}{|c|}{ February-2018 (Summer) } \\
\hline $\begin{array}{c}\text { Inner } \\
\left(65 \mathrm{Km}^{2}\right)\end{array}$ & $8.0 \pm 2.5$ & $16.7 \pm 10.4$ & $15.5 \pm 3.8$ & $17.9 \pm 8.3$ & $-17.7 \pm 8.9$ & $-16.5 \pm 8.4$ & $-19.3 \pm 9.8$ \\
\hline $\begin{array}{c}\text { Central } \\
\left(123 \mathrm{Km}^{2}\right)\end{array}$ & $8.0 \pm 2.5$ & $16.7 \pm 10.4$ & $15.5 \pm 3.8$ & $17.9 \pm 8.3$ & $-1.5 \pm 1.9$ & $-1.4 \pm 1.8$ & $-1.7 \pm 2.1$ \\
\hline $\begin{array}{c}\text { Outer } \\
\left(32 \mathbf{K m}^{2}\right)\end{array}$ & $8.0 \pm 2.5$ & $16.7 \pm 10.4$ & $15.5 \pm 3.8$ & $17.9 \pm 8.3$ & $7.3 \pm 9.8$ & $6.8 \pm 9.2$ & $7.9 \pm 11.0$ \\
\hline $\begin{array}{c}\text { All Lagoon } \\
\text { area- } \\
\text { weighted } \\
\left(220 \mathrm{Km}^{2}\right)\end{array}$ & & & & & -5.01 & -4.67 & -5.50 \\
\hline
\end{tabular}

1010

1011

1012

1013

1014

1015

1016

1017

1018

1019

1020

1021

1022 
Table 3 Comparison between night-time and daytime measurements (moored station) in summer period (February-2017) for the main parameters analyzed in this study.

1026

\begin{tabular}{ccc}
\hline & Night-time & Daytime \\
\hline Salinity & $64.3 \pm 0.13$ & $64.2 \pm 0.70$ \\
\hline Temperature $\left({ }^{\circ} \mathrm{C}\right)$ & $29.4 \pm 0.20$ & $30.0 \pm 0.38$ \\
\hline $\mathrm{DO}(\% \mathrm{Sat})$ & $85 \pm 6$ & $96 \pm 8$ \\
\hline $\mathrm{pH}(\mathrm{NBS})$ & $8.25 \pm 0.01$ & $8.31 \pm 0.02$ \\
\hline $\mathrm{TA}\left(\mu \mathrm{mol} \mathrm{kg}{ }^{-1}\right)$ & $2971 \pm 9$ & $2990 \pm 15$ \\
\hline $\mathrm{DIC}\left(\mu \mathrm{mol} \mathrm{kg}^{-1}\right)$ & $2253 \pm 17$ & 3.050 .52 \\
\hline$\delta^{13} \mathrm{C}-\mathrm{DIC}$ & $2.88 \pm 0.14$ & $385 \pm 25$ \\
\hline$p \mathrm{CO}_{2}(\mathrm{ppmv})$ & $411 \pm 11$ & $44.7 \pm 16.5$ \\
\hline${\mathrm{Chl} \mathrm{a}\left(\mu \mathrm{g} \mathrm{L}^{-1}\right)}_{\mathrm{FCO}}\left(\mathrm{mmolC} \mathrm{m}^{-2} \mathrm{~d}^{-1}\right)$ & $32.6 \pm 1.8$ & \\
$\mathrm{~W} 14$ & & $-3.99 \pm 7.01$ \\
$\mathrm{VD} 19$ & $2.67 \pm 2.59$ & $-2.05 \pm 3.74$ \\
$\mathrm{~J} 08$ & $1.59 \pm 1.54$ & $-4.45 \pm 8.13$ \\
\hline $\mathrm{NCP}\left(\mathrm{mmol} \mathrm{C} \mathrm{m}^{-2} \mathrm{~d}^{-1}\right)$ & $3.25 \pm 3.16$ & 278.8
\end{tabular}

1027

1028

1029

1030

1031

1032

1033

1034

1035

1036

1037

1038

1039

1040

1041

1042

1043

1044

1045 
Fig. 1 Location of the Araruama Lagoon, Brazil. The lagoon was divided into three sectors to analyse spatial heterogeneity: IL (Inner Lagoon), CL (Central Lagoon), OL (Outer Lagoon). The blue line represents the boat track with continuous measurements (nearly the same boat route was made in winter and summer). However, note that the marine end-member outside the channel was sampled on in February. The red circles represent the discrete sampling stations. The green star represents the location of the moored station. The yellow star represents the location of meteorological station.

1053

Fig. 2 Distributions of TA (a), DIC (b) $\delta^{13} \mathrm{C}$-DIC (c), and $p \mathrm{CO}_{2}$ (d) along the salinity gradient. The blue dots represent the winter, and the green dots represent the summer. The dashed blue and green lines represent the theoretical evaporation path. The red line (graph d) represents the average values of atmospheric $p \mathrm{CO}_{2}$.

Fig.3 Maps showing the boat trajectories (black lines) during sampling for winter (a) and summer (f) periods. Below the map on the left side, it is presented the distributions of temperature (b), salinity (c), $p \mathrm{CO}_{2}(\mathrm{~d})$ and $\mathrm{O}_{2}$ (f) vs. latitude, for winter. Below the map on the right side, it is presented the distributions of temperature (g), salinity (h), $p \mathrm{CO}_{2}$ (i) and $\mathrm{O}_{2}$ (j) vs. latitude, for summer. The yellow, black, and red dots represent the inner, central, and outer sectors, respectively. The black line represents the value of atmospheric $p \mathrm{CO}_{2}$ and $\mathrm{O}_{2}$.

Fig. 4 Variation in the partial pressure of $\mathrm{CO}_{2}\left(p \mathrm{CO}_{2}\right.$, ppmv) as a function of dissolved oxygen saturation level (DO\%) in the brines of Araruama Lagoon. The grey circles represent the sampling at day 18-07-2017, which occurred before storm (under low wind speed; $<5.5 \mathrm{~m} \mathrm{~s}^{-1}$ ). The light blue circles represent the sampling after storm (during storm the wind speed overpassed $14 \mathrm{~m} \mathrm{~s}^{-1}$ ).

Fig. 5 Relationship between $p \mathrm{CO}_{2}$ levels and $\mathrm{Chl} a$ concentrations, separated in winter and summer periods.

Fig. 6 Scatter plots of $\delta^{13} \mathrm{C}$-DIC as a function of a) $p \mathrm{CO}_{2}$, b) water temperature, and c) $\mathrm{Chl} a$ concentration. Blue squares represent the sampling in winter, and green circles represent the sampling in summer.

Fig. 7, Time series at the mooring station showing the diurnal variation of DO concentrations and $p \mathrm{CO}_{2}$ values. The shaded area symbolizes the period of night-time measurement. The horizontal black line represents the atmospheric $p \mathrm{CO}_{2}$ and $\mathrm{O}_{2}$.

Fig. 8 The graph a) represents the deviations from evaporative model of TA $(\triangle T A)$ as a function of DIC ( $\triangle \mathrm{DIC})$ in waters of Araruama Lagoon. The solid black lines indicate the direction and slope of the main processes affecting TA and DIC concentrations. The graph b) is plot of $\Delta \delta^{13} \mathrm{C}$-DIC vs. $\Delta$ DIC/DICocean in the Araruama Lagoon. The drawn vectors "photosynthesis" and " $\mathrm{CO}_{2}$ efflux" represent the slopes of these specific processes affecting the DIC and $\delta^{13} \mathrm{C}$-DIC distributions, when DIC concentrations decrease and $\delta^{13} \mathrm{C}$-DIC values increase. The drawn vector " $\mathrm{CaCO}_{3}$ precipitation" represents the slope of this specific process, when DIC concentrations and $\delta^{13} \mathrm{C}$-DIC values decrease. The drawn vector " $\mathrm{CO}_{2}$ influx" represents the slope of this specific process, when DIC concentrations increase and $\delta^{13} \mathrm{C}$-DIC values decrease. Blue dots are the winter stations, and green dots are the summer stations. The origin of these graphs (represented by the black " $x$ ") indicate no deviation from the evaporative model (see material and methods section 2.3.4 for further explanation). 
1097

1098

1099

1100

1101

Fig. 1

Fig. 9 Relationship between E-DIC and AOU. Blue dots are the winter stations, and green dots are the summer stations. The 1:1 line represents the quotient between $\mathrm{CO}_{2}$ and $\mathrm{O}_{2}$ during the processes of photosynthesis and respiration.

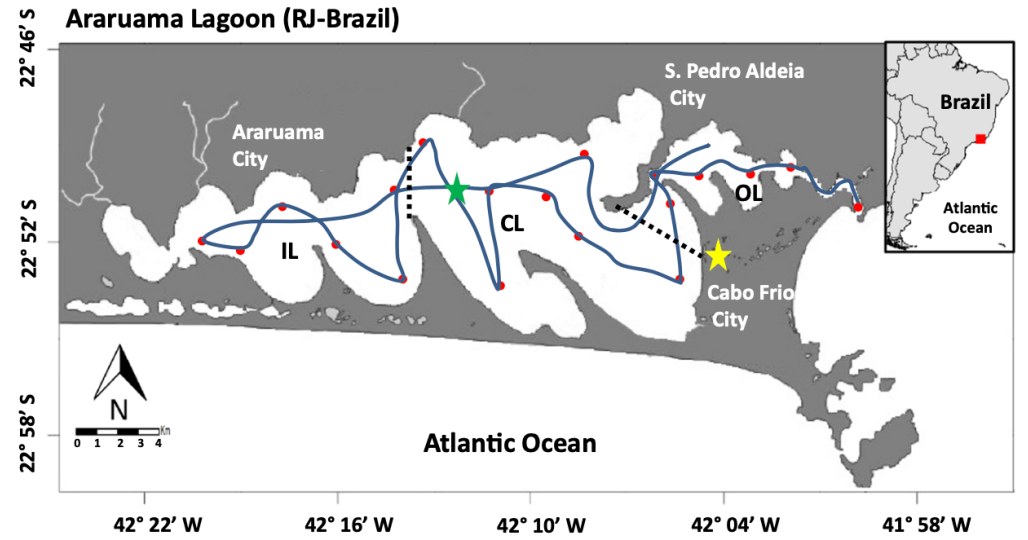


Fig. 2
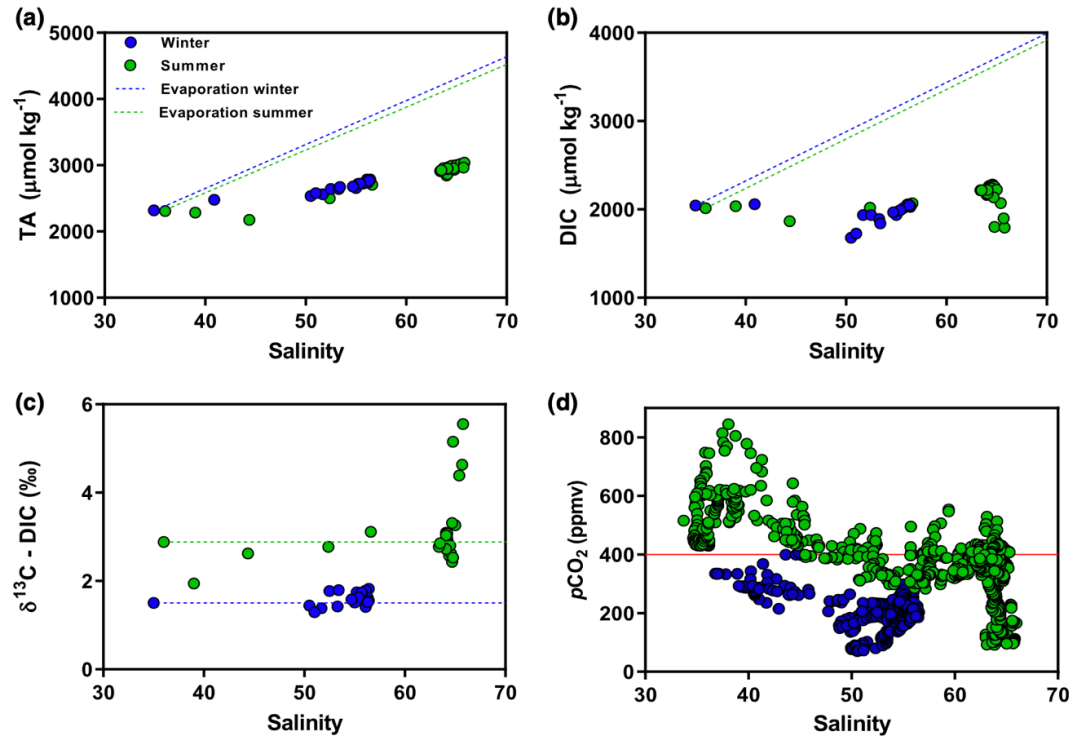
1131 Fig. 3

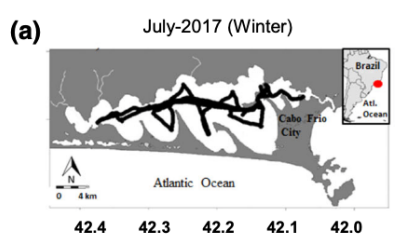

(b)
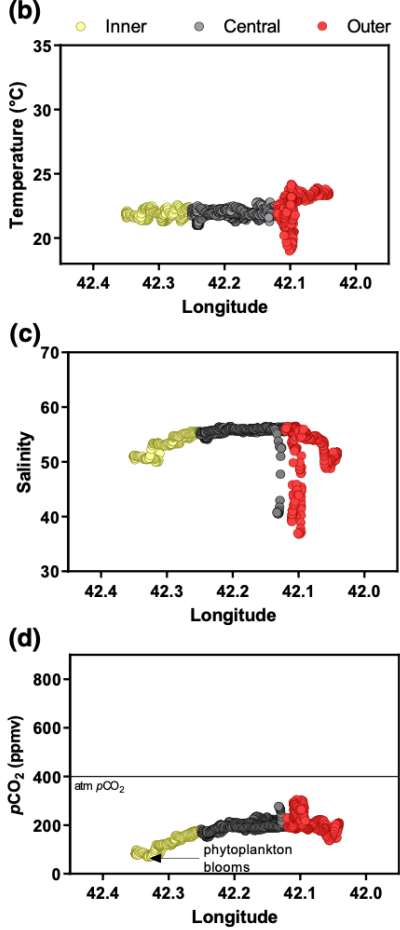

(e)

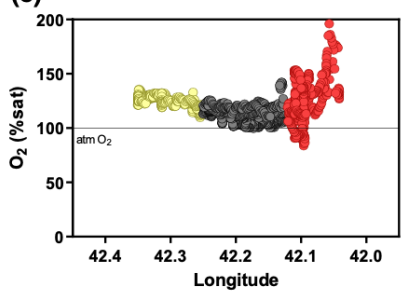

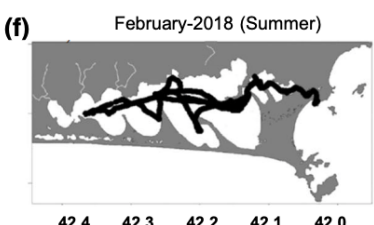
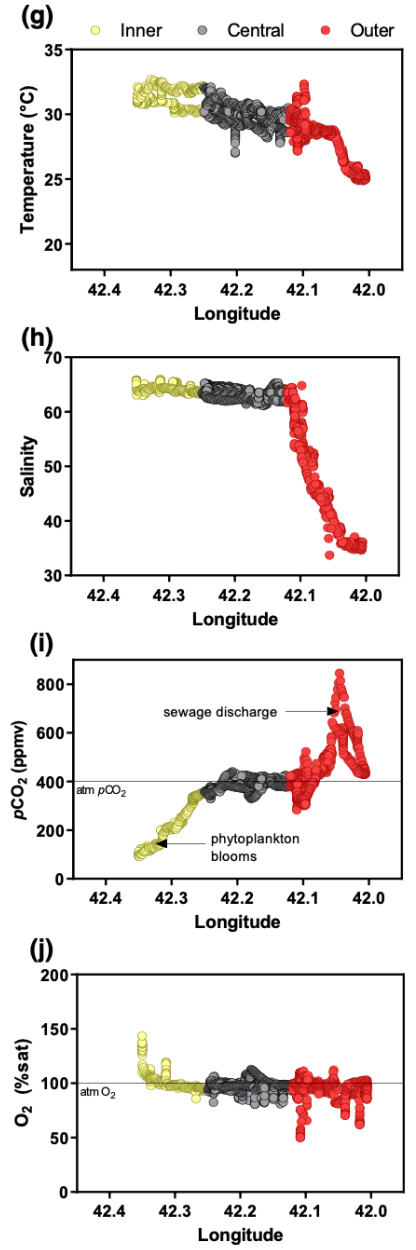
Fig. 4

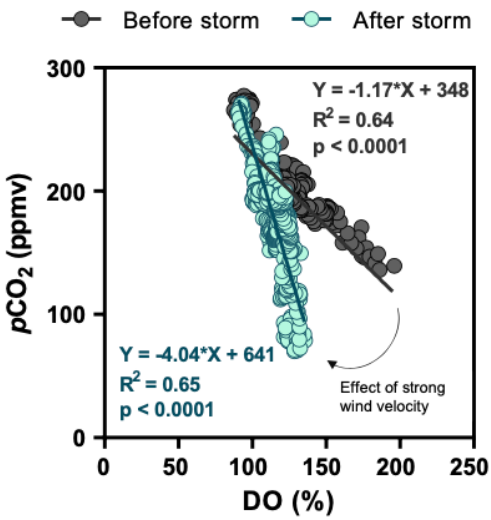

1136

1137

1138

1139

Fig. 5

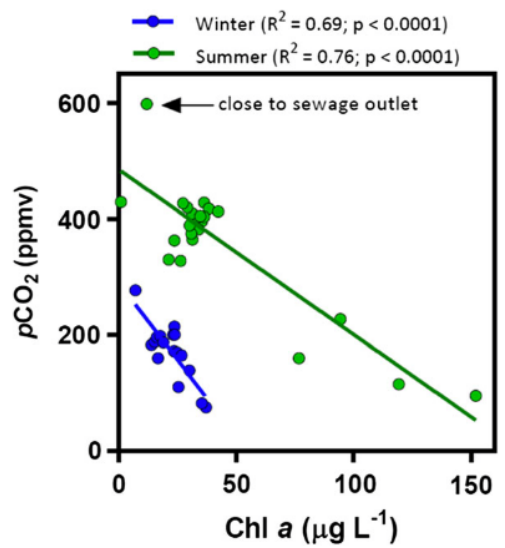


Fig. 6
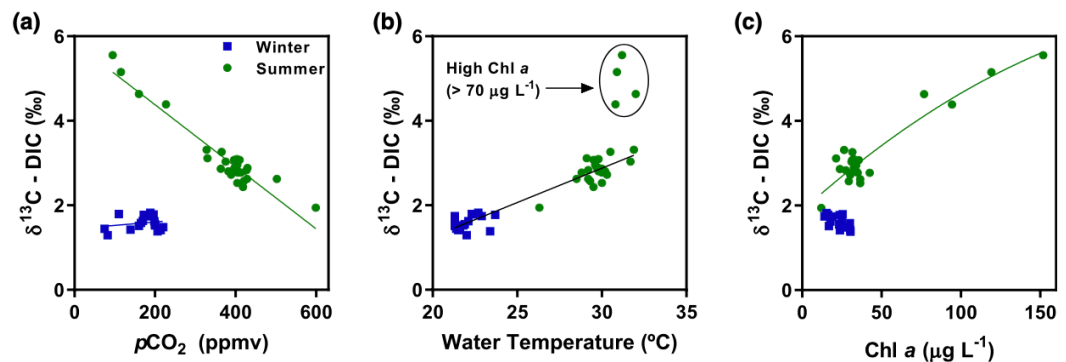

1148

Fig. 7

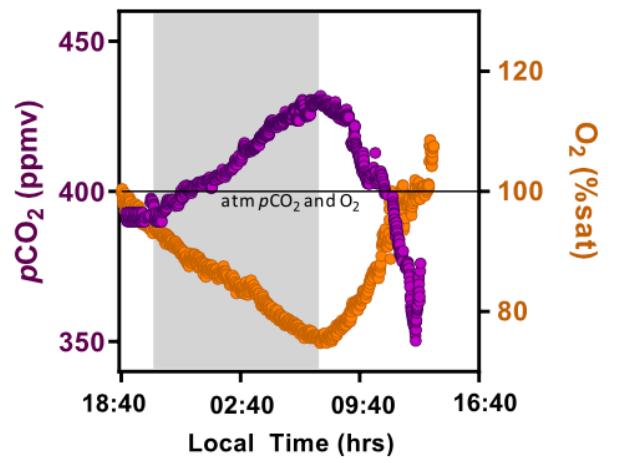

1150

1151

1152

Fig. 8
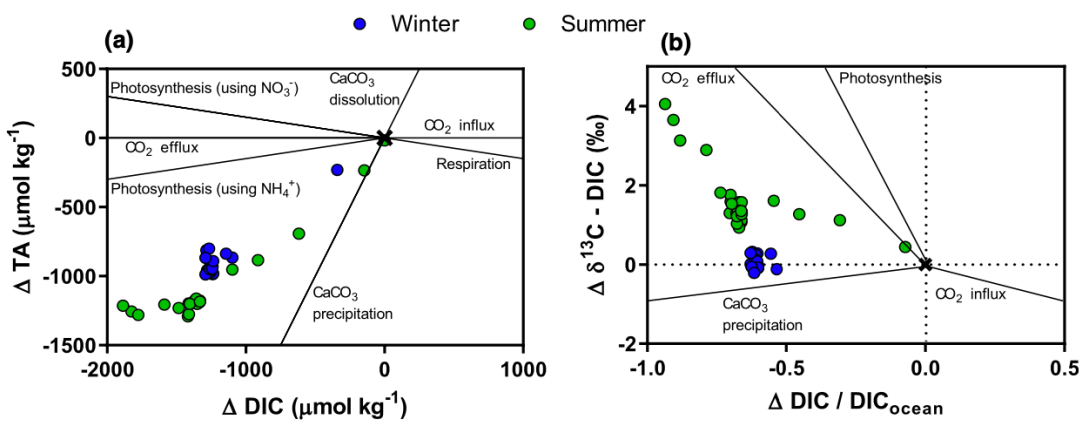
1157 Fig. 9

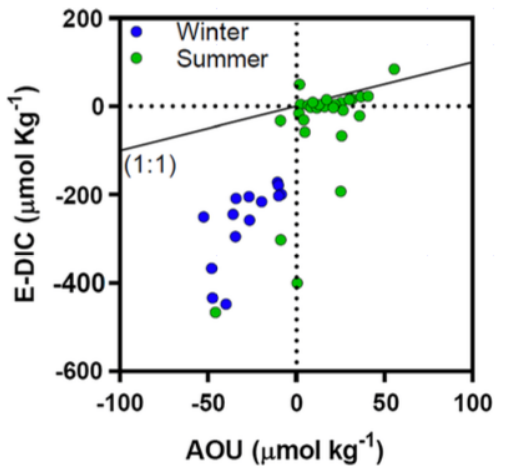

1158

1159

1160

1161

1162 